\title{
The Study of Medicine
}

In the sixteenth and seventeenth centuries, students from north of the Alps flocked to the universities of Northern Italy, mainly Padua and Bologna. Although there were quite a number of universities north of the Alps that had their own faculties of medicine, a Europe-wide comparison yields striking differences. At most of the late medieval universities in German-speaking areas - and the situation was similar in England and large parts of France ${ }^{114}$ - the faculty of medicine played a rather insignificant role. ${ }^{115}$ It stood in the shadow of the arts faculty and the other two higher faculties, theology and law. Some faculties of medicine employed only a single professor and even in places where there were two or three professors of medicine, they were often little known, unrenowned individuals. The number of medical students was also very modest in most cases and the number who received a medical degree was even smaller. According to the matriculation records in Cologne, for example, only about 0.4 percent of students studied medicine there in the time between the late fourteenth and the early sixteenth centuries. ${ }^{116}$ During about the same time period in Erfurt, there was a total of sixty-four medical graduates, including those who had followed up their studies in the local arts faculty with medical studies. Medical scholars and students there did not even have their own lecture hall. ${ }^{117}$ And even in Basel, where at the end of the sixteenth century a considerable number of medical students received their doctorates, the situation was described as unsatisfactory by Georg Keller: of the two professors, one, Johannes Huber, was considered a practitioner more than anything else and the second, Isaak Keller, did not enjoy a good reputation. ${ }^{118}$

At the leading universities in Italy - and the same was true in France in Montpellier and Paris - the situation was very different. There medicine was more or less on par with the two other higher faculties with respect to the number of students and lecturers, but also with respect to status, and this found expression not least of all in the remuneration of the professors. In addition, a certain degree of religious tolerance was extended, at least to foreigners. ${ }^{119}$ Accordingly,

114 Lunel, Maison (2008), p. 31.

115 On medical education in the universities of the various European countries, see Siriasi, Medicine (2001); with a focus on the German universities Nutton, Medicine (1997), pp. 173-190 and on those in the Netherlands Lindeboom, Medical education (1970), pp. 201-234.

116 Abe, Medizinische Fakultät (1974), p. 26, on the figures for Cologne.

117 Ibid., p. 28.

118 Schieß, Briefe (1906), p. 11.

119 Although Johann Schwartz was full of praise for the University of Padua in the 1570s, he preferred to take his doctorate in Basel because he would have had to take a papal oath in

Ә Open Access. (C) 2022 Michael Stolberg, published by De Gruyter. (c) BY-NC-ND This work is licensed under the Creative Commons Attribution-NonCommercial-NoDerivatives 4.0 International License. https://doi.org/10.1515/9783110733549-003 
the aforementioned universities attracted many medical students from north of the Alps. ${ }^{120}$ Precise numbers are lacking, but a look at physician biographies even suggests that it was more a rule than an exception for physicians from German-speaking areas to do their training (and often receive their doctorates) in Italy or the south of France until well into the sixteenth century. ${ }^{121}$ This gradually began to change in the second half of the sixteenth century when Basel and Wittenberg increasingly attracted medical students.

By far, the most predominant form of transferring knowledge at universities across Europe throughout the entire early modern period and for all disciplines was the lectura, the lecture. ${ }^{122}$ Lectures gave shape to teaching activities and set the daily, weekly, and annual rhythm of academic life. In Padua and Montpellier, but also in Ingolstadt for example, the lecture period ran from late autumn to early summer. ${ }^{123}$ In Padua, the anatomical demonstrations were held over the Christmas holiday, ${ }^{124}$ and the winter carnival in nearby Venice caused long interruptions. As Georg Keller complained, no collegia were held during his first year in Padua between January 21 and March 4. ${ }^{125}$ Teaching activities were sometimes disturbed for even longer periods by epidemics. In times of pestilence, students found themselves needing to move to other university towns that had not yet been affected - if they were still allowed to do so. In his letters, Georg Keller described the drastic measures to which everyone, including of course students, was subjected when the plague befell Padua in 1555. Houses that were suspect were barricaded, the town gates closed. He had already experienced something similar in Paris. ${ }^{126}$

Generally, lectures were held in the morning and in the afternoon, five days a week. Usually no lectures were held on one workday. The university in Padua

Padua (HStA Stuttgart, A 282, Bü 1301, supplication by Johann Schwartz to Duke Ludwig of Württemberg, submitted 26 April 1576; ibid., letter from Schwartz' father-in-law, Samuel Heiland, 6 April 6 [1575]).

120 Cf. Germain, Les pèlerins (1878), vol. 1, pp. 161-181.

121 See also Dotzauer, Deutsches Studium (1974).

122 Overviews of medical education in the sixteenth century in O'Malley, Medical education (1970), pp. 89-102; Talbot, Medical education (1970), pp. 73-87; Siraisi, Faculty of medicine (1992), pp. 360-387; Nutton/Porter, History (1995); Nutton, Medicine (1997), pp. 173-187; Brockliss, Curricula (1996), pp. 565-567; Siraisi, Medicine (2001).

123 In Padua, the academic year was usually inaugurated on the day after All Saints' Day (Bertolaso, Ricerche (1958-59), p. 19).

124 Adam, Vitae (1620), p. 205.

125 Zentralbibliothek Zürich, Ms F 38, fol. 30bis r, letter from Keller to R. Gwalther, 10 March [1552]; cf. Schieß, Briefe (1906), pp. 7f., letter from Padua, 26 February 1551.

126 Schieß, Briefe (1906), p. 18, letter, 4 October 1555. 
was unique insofar as two professors who had the same areas of specialization would give their lectures at the same hour and would thus enter into direct competition with each other. When Joachim Curaeus went to Padua in 1557, Vettore Trincavella, for example, whom Curaeus considered to be the more learned professor, was competed against Antonio Fracanzano, who according to Curaeus knew better how to attract students with his well-chosen words. ${ }^{127}$ In these circumstances it was especially important in Padua to coordinate the times of the lectures. Statutes precisely regulated the schedule. Immediately following the tolling of the morning bells, the professors for theoretical medicine would start the morning lecture. Unlike for professors with other specializations, they were required under the threat of disciplinary action to read for at least two hours. Subsequently, associate professors lectured on medicina practica. In the afternoon until Easter at the $21^{\text {st }}$ hour and after Easter at the $19^{\text {th }}$ hour (in Padua, the first hour started at sunset the previous evening) - the associate professors of theoretical medicine delivered their lectures followed by the full professors of medicina practica. $^{128}$

The term "lecture" has endured to the present day, but for the early modern period it is to be taken quite literally. In the traditional lecture, the lecturer read from an authoritative text, explaining the meaning sentence by sentence or passage by passage. Supported by a firm grasp of Latin, a basic knowledge of natural philosophy, and critical evaluation skills acquired through training in Aristotelian logic, prospective physicians gained significant knowledge during these lectures in which a professor introduced texts, interpreted difficult passages, and weighed conflicting opinions or tried to reconcile them.

With the so-called Articella, a certain canon of authoritative texts had already become established in the Middle Ages. The central texts of this collection of writing, which has its origins in the Salerno medical school, remained influential in the medical teaching of the Renaissance: the Hippocratic Aphorisms with Galen's commentary, Hippocrates' Book of Prognostics, and Galen's Ars parva with the introduction ("Isagoge") by Hunain ibn Ishāq (Iohannitius). Since the High Middle Ages, Avicenna's Canon medicinae had served as a further central textbook. In contrast to the loose succession of the numerous writings by Galen and the short, largely unstructured propositions of the Hippocratic Aphorisms, Avicenna's work offered a systematic survey of medicine as a whole and could thus serve as a first-rate textbook. ${ }^{129}$ The curriculum that was set forth in the statutes of Padua in

127 Adam, Vitae (1620), pp. 204f.

128 Bertolaso, Ricerche (1958-59) gives a list of the holders of the individual chairs; the major early modern source is Facciolati, Fasti (1757).

129 Avicenna, Canon (1595); Siraisi, Avicenna (1987). 
1495 largely still corresponded with this traditional canon of writings. First-year students had to read the entire first book of the Canon, followed in the second year by the Hippocratic aphorisms and Galen's commentary and, if time permitted, Hippocrates' writings on prognosis. In the third year, Galen's Ars parva was next in line. ${ }^{130}$

With the rise of humanism, some physicians, buttressed by their excellent knowledge of Latin and Greek, made it their mission to significantly expand the traditional teaching canon. In their investigations of old manuscripts, they discovered medical texts of ancient authorities that had remained unknown thus far, especially those from the Hippocratic school and by Galen. Toiling collectively, they went through the collected Greek works of Hippocrates and Galen, producing numerous translations of the ancient writings in elegant, humanist Latin. ${ }^{131}$ The spectrum of available writings was thus greatly expanded, so that Jacobus Sylvius, for example, in his Ordo et ordinis ratio in legendis Hippocratis et Galeni libris (1548), was able to list dozens of works by Galen, Hippocrates, and other authorities in thematic order. For university teaching, however, this richness also presented new challenges. In a disclaimer to his list, Sylvius commented that it would be exceedingly protracted and onerous ("longissimum et molestissimum") to treat all of these works in medical teaching. His personal selection was already extensive enough. As one could gather from his lectures, he limited himself to certain works for each of the different areas of medicine. He named about fifteen works in particular, most of them by Galen.

For some in the medical profession, medical humanism brought with it pronounced anti-Arab sentiment. ${ }^{132}$ Certain physicians pulled Persian and Arabic physicians to pieces along with their "barbaric" medicine, and even wanted to see them banned from the medical curriculum. ${ }^{133}$ Others considered a deficient translation of these works to be the problem. Even some of the humanist admirers of Hippocrates and Galen had to admit, however, that the writings they

130 Statuta (c. 1600 [?]), book 2, XVI; this is probably a later print - the statutes are clearly dated 1495.

131 The literature on this topic is extensive; a good first orientation is provided by Durling, Census (1961); Bylebyl, Medicine (1985); Boudon-Miller/Cobolet, Lire les médecins Grecs (2004); Fortuna, Latin editions (2012). Vivian Nutton has explored various aspects of medical humanism in numerous contributions; see idem, Diffusion (2002); idem, Hippocrates (1989); idem, John Caius (1984). An excellent overview of the situation in Padua can be found in Bylebyl, School of Padua (1979).

132 Germain, La médecine arabe (1877); Baader, Medizinische Theorie (1987).

133 Cornarius, Medicina (1556), pp. 116-119. 
had left behind were not nearly as extensive and thorough as Avicenna's systematic survey of the whole field of medicine in his Canon medicinae. It was not until the second half of the sixteenth century that the Canon was challenged by a serious competitor in the form of the Universa medicina by Jean Fernel (1497-1558). Based on Galen but developing his medicine further, Fernel gave a comprehensive overview of the entirety of theoretical and practical medicine, one that was comparable to the Canon but more readable, up-to-date, and succinct. His work remained very influential until well into the seventeenth century. ${ }^{134}$

As a result of the intensive editing and translation work of the medical humanists, the Canon, Rhazes's Ad Almansorem and other leading works of Persian and Arabic medicine gradually lost significance. In no way, however, did they become obsolete. At leading Italian universities as elsewhere, the Canon remained a pillar of medical teaching. ${ }^{135}$ In Padua - and this is also shown by Handsch's extensive lecture notes - the Canon and Ad Almansorem still made up the core curriculum around 1550, along with Galen's Ars parva and the Hippocratic Aphorisms. ${ }^{136}$

The most important source in historical research about university teaching has traditionally been the historical statutes listing the set texts that were to be commented on in lectures. These lists, however, give an incomplete view of the actual lectures. Not only did they lag behind the actual teaching practice, frequently laying down what had actually been long established in teaching practice. ${ }^{137}$ They also represent only a part of the teaching activity. Looking only at these lists, essential elements of medical training remain largely invisible.

A more precise and detailed picture of the medical teaching can be gained by looking at student notes. Happily, a wealth of such notes from the sixteenth century has survived, but not much of it has been systematically researched. ${ }^{138}$ The notes vary widely with respect to the form they take. Sometimes students wrote down the lecture word for word. This went so far that they even reproduced forms of address such as "you young men" ("vos juvenes"), used by the

134 Fernel, Universa medicina (1644); Sherrington, Endeavour (1946); Roger, Fernel (1960); Hirai, Medical humanism (2011), pp. 46-79.

135 Siraisi, Avicenna (1987).

136 Under the heading "leguntur Paduae", Handsch explicitly listed the works mentioned and only these (Cod. 11240, fol. 28r); even in the early seventeenth century there was still a chair in Padua with the denomination "Ad lecturam secundae fen primi Canonis Avicennae" (Bertolaso, La cattedra (1960), p. 113). On the humanistic reception of Galen's Ars parva see Mugnai Carrara, Epistemological problems (1999).

137 Brockliss, Curricula (1996), p. 563.

138 In the course of my research, I have so far been able to identify more than two dozen such handwritten lecture notes from Padua alone. 
lecturer. It was also not unusual for them to retain the use of the first person ("ego") in their notes when the lecturer made statements about his own experience or relayed his personal opinion. At the other end of the spectrum there are short, sketchy notes only about certain aspects that struck the student as noteworthy and important to remember. In Handsch's Padua notebooks we find the whole range, from dictata to short, loose notes.

From Handsch's notes as well as those of other contemporary students, two important developments come to light which find only very incomplete expression in the statutes. First, the professors did much of their teaching privately, outside the official, curricular courses, with smaller groups of students. As we will see, "private" lessons given to a limited group of paying students were especially important in teaching anatomy. They were, in fact, far more important in helping students gain anatomical knowledge and skills than the large public anatomy demonstrations which have so far been the focus of historical research on anatomical instruction in the early modern period.

Second, the sixteenth century saw an increase in the significance, at least at the Italian universities, of lectures with a thematic orientation. Here the professor did not comment on one specific text. Instead he would treat a certain subject area, drawing on the works of different authors and sometimes on personal, practical experience as well. Giovanni Battista da Monte was once more among the trailblazers who, as his student Girolamo Donzellini emphasized, not only explained authoritative works, but treated important subjects separately. ${ }^{139}$ In Padua, Handsch heard the private lectures of Fracanzano on diseases of women and took notes during private, at-home lectures about stomach diseases, which were given by Trincavella on holidays. ${ }^{140}$ Handsch's notes on a lecture by Fracanzano about the French disease also give the distinct impression of a private lecture. ${ }^{141}$ A couple of years later, another student in Padua took notes on Fracanzano's lectiones extraordinariae on fever symptoms. ${ }^{142}$ During those years, Bellocati lectured, again “extra ordinem”, about children's diseases, while Trincavella, in

139 Da Monte, Opuscula (1558), vol. 1, dedicatory epistle by Donzellini to Giulio Alessandrini: "Solebat enim ille, praeter seriem authorum, quos explicabat, peculiares aliquando tractationes facere, in quibus de rebus maxime necessariis auditores erudiebat, et ad authores ipsos exactius intelligendos magno eorum emolumento instituebat.”

140 Cod. 11226, fol. 160v.

141 Ibid., foll. 92r-119r, from 16 December 1551; ibid., foll. 123r-140r; cf. Fracanzano, De morbo (1564) (based on student notes on Fracanzano's lectures in Bologna). Fracanzano taught in Padua from 1538, first logic and then medical theory. He went to Bologna in 1555 and returned to Padua in 1564 (Mantese, Storia (1969, pp. 64-66).

142 Biblioteca dell'Arciginnasio, Bologna, Ms. A 46, title according to the heading of the index on fol. 143 r. 
addition to his lectures about Avicenna's writing about fevers as well as about Rhazes's teachings on the diseases of the head and chest, taught "extra ordinem" about "worms" and "arthritis". 143

The authors of contemporary study guides put great emphasis on attending lectures. Johannes Brettschneider (aka Placotomus, 1514-1577), for example, stressed that in no way should students choose independent study over a lecture. He held that a lesson with a living voice ("viva voce") best allowed medical doctrine to be imparted as the voice had something of a "hidden energy" ("energiae latentis"). No one could learn the pensum of a lesson on his own with equal success. ${ }^{144}$

The transcripts of good lectures were, however, valuable to students who could not attend the lecture. Some lectures were even printed and published from student notes. It seems a certain demand for them was to be expected. And students would also request handwritten copies of lecture notes from each other. ${ }^{145}$ Such a copy of a lecture, written in another man's hand is also found among the manuscripts in Handsch's Nachlass. It was a lecture that Augustin Schurff had given years earlier in Wittenberg, and Handsch wrote his own supplementary notes in the margins. ${ }^{146}$

Not only were students urged to attend lectures; intensive preparatory and follow-up work was also recommended. Student guidebooks like the one by Brettschneider even advised students to read the passages from an authoritative text that were to be addressed in the lecture at home beforehand. After the lecture, they were then supposed to carefully go through their notes and excerpt the most important topics, theorems, problems, and questions in a diarium. It was also said to be useful to talk and compare notes with other students, since presenting to others what one had learned was a good schooling for the mind. At the end of the week, it was then advisable to go through the week's notes, now organized thematically, and to enter them in a second, permanent notebook, one that allowed entries on certain subjects to be looked up and the grasped material to be committed to memory. It was furthermore recommended to learn one

143 Adam, Vitae (1620), p. 205.

144 Placotomus [Brettschneider], De ratione (1552); Adam, Vitae (1620), p. 204 attributes the same notion to Joachim Curaeus.

145 See e.g. Planerio, Epistolae (1584), letter to Franciscus Ticinensis, 1 January 1536, responding to a request for a copy of the "lectiones ordinarias".

146 Cod. 11228, “Annotationes in Nonum Rhasis ad Almansorem dictatae a doctore Augustino Schurphio in schola Vitebergensi Anno 1537". In the back cover, we find the name "Hanns Adlerus", possibly the name of the writer; in the Corpus Inscriptorum Vitebergense, however, no student of this name can be found (https://www.civ-online.org/de/service/startseite/). 
theorem by heart every day. Within just a year, one would thus gain a considerable wealth of knowledge. ${ }^{147}$ Such recommendations were taken to heart. Georg Handsch sketched a very similar two-step process. From one's unorganized lecture notes it was advisable to first gain an overview of the subjects that had been treated and then to enter the notes in a book, organizing them under different headings. ${ }^{148}$

Above and beyond the lectures the students also - and this was expected of them - studied the medical literature independently. The long summer vacations in particular provided opportunity for this. Some students appear to have acquired their medical knowledge almost exclusively from reading books. This was particularly true of those who started out in other areas and earned their living doing non-medical activities. The thirty-seven-year-old humanist and poet Helius Eobanus Hessus, for example, a long-time teacher of Latin at the University of Erfurt, said he had been reading Galen's works for a long time and it seemed to him that he had gained extensive knowledge of medical theory. All he was missing, he said, was practical experience and the doctor title. ${ }^{149}$

Contemporary reading- and study- guides provided extensive recommendations for students on how they could work methodically and commit what they read to memory. It was important first of all to make a careful selection of authors and works. In his De ratione discendi medicinam epigraphe, Girolamo Mercuriale asserted that one should concentrate on the recognized authorities. Students were warned not to attain their medical knowledge from compendia or summaries. According to Mercuriale, one should even avoid reading commentary if possible; it was better to penetrate the text oneself. The only exceptions here were the works of Hippocrates, with its dark passages, and Avicenna's Canon. ${ }^{150}$

The study guides recommended concentrating on not more than a few works at the same time. As Brettschneider put it, the person who ate too many dishes at once ruined his stomach and the same was true of reading. ${ }^{151}$ Mercuriale made the specific recommendation that only one or two authors should be studied closely at once; they should be read each day at the same time, preferably in the early

147 Placotomus [Brettschneider], De ratione (1552).

148 Cod. 11239, fol. 100v.

149 Hessus, Helii Eobani Hessi (1543), pp. 112-115, Brief an Georg Sturtz, 14.3.1525 (www.aer ztebriefe.de/id/00013019, M. Bleistein); Hessus asked Sturtz, who had left Erfurt and settled as a physician in Annaberg, for support, just as he had given it to his student Euricius Cordus; in a subsequent letter to Sturtz, dated 5 June 1525 (ibid., pp. 118-9), Hessus also referred to his medical studies.

150 Mercuriale, De ratione (1607); see also Durling, Girolamo Mercuriale’s De modo studendi (1991).

151 Placotomus, De ratione (1552), no pagination. 
morning hours and in the evening. ${ }^{152}$ It was helpful, in Johannes Brettschneider's view, to proceed from the simple and general to the more specific. Not all books required the same amount of study. Some had to be read again and again ("crebro"), while others needed to be picked up only a few times or once. ${ }^{153}$ Despite these qualifications, the long lists of recommended authors in reading- and study guides indicate a reading load far too great to be reasonably tackled. ${ }^{154}$ Mercuriale further underlined to prospective physicians the importance of reading the poets and historians: Homer, Hesiod, Lucretius, Virgil, Horace, Juvenal, Martial, Columella, Vitruvius, Herodotus, Strabo, Pausanias, and others. Galen for his part quoted from them repeatedly and thus, according to Mercuriale, it was appropriate to branch out and collect whatever served the enrichment and adornment of medicine. ${ }^{155}$ Not surprisingly, when Isaac Habrecht prefixed his notebook from around 1600 with an extensive list of well over sixty ancient and contemporary works, these writings found only very limited expression in his excerpts. For the most part, his notes focused on introductory institutiones and surveys like those by Jean Fernel and Leonhard Fuchs. ${ }^{156}$

\section{Theoretical Medicine}

In medicina theorica, students first learned to grasp the essence of medicine, to define it and to name its various branches. One of Handsch's Padua notebooks accordingly offers an overview of the terminology and classifications as we know them from numerous printed works of the time. ${ }^{157}$ The source of his knowledge is unclear, but the systematic approach and the occasional rejection of certain parts of academic wisdom point to a lecture, perhaps by Bassiano Landi. ${ }^{158}$ He began with Galen's oft-cited definition of medicine: medicine was the art that protected existing health, improved impaired health, and restored lost health. ${ }^{159}$ As Handsch noted, speaking of health that was only "impaired" - as opposed to

152 Mercuriale, De ratione (1607), pp. 34-35.

153 Placotomus, De ratione (1552).

154 Stainpeiss, Liber (1520); cf. Pawlik, Martin Stainpeis (1980); Pons, Medicus (1600).

155 Mercuriale, De ratione (1607), p. 25.

156 Det Kongelige Bibliotek, Copenhagen, Ms. Gl. Kongl. 4 1691, medical notes of Isaac Habrecht (1606).

157 Cod. 11210; the title which Handsch gave to it was "Compendium medicinae collectum Patavii A[nno] 1551".

158 On Landi see Ferretto, Bassiano Landi (2006-2009) and Ferretto, Maestri (2012).

159 Cod. 11210, fol. 2r: "Est ars quae sanitatem praesentem custodit, viciatam emendat, et amissam restaurat”. 
"existing" and "lost" health - referred to a Galenic concept that was heavily discussed at the time, that of a "neutral state" between disease and health. ${ }^{160}$ Medicine was a "scientia" insofar as it considered the causes of illness, the nature of human beings, and the efficacy of medicines. At the same time, it was a craft or an "acting art" ("ars factiva"), insofar as it was practiced. Its subject was the human body; its goal was health. ${ }^{161}$ This was a goal it could not always achieve, however. What was crucial was to act in such a way that health was served, even if success sometimes failed to materialize. ${ }^{162}$ Medicine consisted of a preventative and a curative part. Curative medicine consisted of medicinal, dietetic, and surgical or manual treatment. ${ }^{163}$

According to Handsch's notes, this was followed by a short overview of ancient medical schools after Galen. The following distinction was another topos of contemporary medical literature: on the one hand, the "empiricists" ("empirici") treated diseases based only on their experience ("suis experimentis"), without reason ("ratio") and judgment ("iudicium"). ${ }^{164}$ The "dogmatic" ("dogmatici”) or "rational" ("rationales") physicians on the other hand considered human nature and the causes and fortuities of diseases on the basis of early, present, and future signs and used remedies on patients with rationality and the most finely-attuned ability to judge ("exquisito cum iudicio"). ${ }^{165}$ According to Galen, reason ("ratio") and experience ("experientia”) were the legs on which medicine stood. ${ }^{166}$

Essential for a rational, scientific approach as per contemporary standards were the fundamental principles of natural philosophy. Knowledge based on natural philosophy about the construction, the faculties, and the functions of the human body and its parts - which is to say, knowledge about physiologia, as it was already called at the time - was indeed an indispensable requirement for the understanding, the diagnosis, and the treatment of illnesses.

Aspiring physicians were told and they read that the human body was composed like everything in nature of the four elements: fire, earth, water, and air. To each of these a combination of two of the four primary qualities - hot, cold, dry, and moist - was assigned. Naturally, what was even more important in understanding the human body and its functions were the four humors, whose

160 Joutsivuo, Scholastic tradition (1999).

161 Cod. 11210, fol. 2r.

162 Ibid.

163 Ibid., fol. 2v; the third medical sect commonly discussed in this context were the methodists who attributed diseases to an excessive widening or narrowing of the ducts in the body.

164 Ibid.

165 Ibid.

166 Ibid. 
existence ancient medicine had already postulated on the basis of the teaching of the elements: yellow and black bile, phlegm, and blood. As with the elements, each of these was assigned a pair of primary qualities. Yellow bile was hot and dry; black bile was cold and dry; phlegm was cold and moist; and blood was hot and moist. The individual combination of the four humors in the body resulted in the temperament of the person in question, or, with respect to the qualities, in the person's complexio. Temperament or complexio was often recognized in external features such as the color of the hair and face. The English word "complexion" still denotes facial color or countenance today. The humors also, however, had a far-reaching effect on what was taking place within the body and they determined not least of all the temperament as we define it today. If yellow bile predominated, the resulting “choleric" (from Greek, chole = yellow bile) temperament would lead to a tendency toward fits of anger. If, on the other hand, viscous, slimy phlegm was predominant, one could expect a thoughtful or even sleepy nature - a "phlegmatic" nature as we still say today. The individual combination of humors and qualities was innate, but it was subject to change with age and the influence of the external environment.

To properly understand the physical functions and processes within the body, it was essential to have a knowledge of the body's faculties, the so-called facultates or virtutes such as the facultas expulsiva, the facultas motrix, and the facultas cogitativa. From today's perspective, they may seem like a mere theoretical construct, even like empty words, but from the perspective of the time, they were indispensable to understanding human (and animal) physiology. They emerged from Aristotelian natural philosophy, according to which every motion and thus every change had an efficient cause. In the healthy human body, changes were constantly at work: matter was moved, food was assimilated, excretions were taking place, and a host of further functions were carried out, all without an identifiable source of the movement and change. Even if a movement could be traced to a person's will, there was still the question of how a decision made by the immaterial soul could have the very concrete effect of moving a finger or the leg. This gap was filled by the concept of nature in general but in particular by its concretization in the facultates. Handsch noted a succinct definition: "The faculty ["virtus"] is the cause that precedes the action." ${ }^{167}$ And, conversely: "when the faculty perishes, there is no action."168

Three general virtutes or facultates were to be distinguished which "governed" ("gubernant") and preserved the body. Handsch made a carefully

167 Ibid., fol. 41v.

168 Ibid., fol. 42r: "Si facultas perit, nulla sequitur actio." 
subdivided list here. First there was the mental faculty, the facultas animalis, which had its seat in the brain and communicated sensations and conscious, deliberate movements via the nerves. Cognitive faculties in a narrower sense were subdivided into the imagination, judgment, and memory. Second, there was the facultas vitalis, which had its primary seat in the heart. And third, there was the facultas naturalis, the natural faculty that ensured the alimentation of the body. ${ }^{169}$

The vital and the animal faculties - whether the natural faculty could be included here remained subject to debate - required a material instrument that would allow them to take effect not only in their particular location but throughout the whole body. This came in the form of the spiritus, a further key concept of contemporary physiology. The spiritus vitalis was, as we find in the standard definition noted by Handsch, a "subtle, airy, transparent substance that is produced from the most delicate part of the blood so that the faculties can be taken from the main parts to the other [parts], so that they can carry out their specific activities". ${ }^{170}$ This spiritus vitalis was generated with the help of the innate, vital heat ("insiti et nativi caloris causa existens"). It was produced in the left chamber of the heart from delicate blood and inhaled air and it flowed through the arteries into the rest of the body. ${ }^{171}$ Parts of this spiritus vitalis were refined in the brain or, as Handsch wrote, in the plexus reticularis to become the spiritus animalis, or animal spirit, which spread throughout the entire body via the nerves and was responsible for movement and sensation. ${ }^{172}$

A central task of the natural faculties and of vital heat, the calor innatus, was the assimilation of ingested food. This process had presented learned physicians with a puzzle since antiquity. How was the body able to quite literally assimilate the wild mix of comestibles that it took in daily, producing material that belonged to the body, as the growth of children and adolescents so impressively illustrated? How could milk, grits, porridge, bread, and the like be made similar to or indeed transformed into bodily substance, into muscles, bones, and individual organs? In the case of adults, the necessity of the constant assimilation of food that was foreign to the body was not quite as apparent. ${ }^{173}$ Stories of young women who had reportedly not eaten for years lent credence to the idea that the human body was not crucially dependent on a constant intake of food. These apparent miracles of fasting were, however, a frequent subject of controversy among physicians and were sometimes exposed as frauds - for example when the woman said to be

169 Ibid., fol. $41 \mathrm{v}$.

170 Ibid., fol. 42v.

171 Ibid.

172 Ibid., foll. 42v-43r.

173 Ibid., fol. 50r. 
fasting had, as it turned out, drunk her mother's breastmilk when she came to visit. ${ }^{174}$ Physicians assumed that the adult body, too, required constant nutrition because it was always using up or losing substance and it needed to offset this loss. Handsch noted: "Children and adolescents eat so that they may grow, [while] adults eat only to preserve their bodies”.

Models explaining the process by which food was assimilated had already been developed by ancient physicians, and constituted basic knowledge that every aspiring physician in the early modern period had to learn. To summarize the essential: Galenic medicine described the assimilation of food quite literally as a cooking process. Just as food was cooked on the kitchen stove, vital heat within the body concocted the ingested food in several steps, separating that which was of use - so that it could be appropriated by the body - from the useless, which had to be excreted. ${ }^{175}$ In a first step - and this was also learned by Handsch - food was concocted in the stomach. Useless, coarse, and dry matter was excreted as feces via the bowel. Via the abdominal veins, the more delicate matter was transported as liquid food or chymus to the liver, where in a second step it was concocted to become nutritious blood that made its way to all parts of the body through the veins. Unusable matter was also separated out in this second concoction process; it was transported for the most part to the gall bladder as yellow bile and ultimately emptied into the bowel. Further substances were carried to the spleen as black bile. The superfluous watery matter, finally, accompanied the blood first in the large vena cava but was then attracted by the kidneys together with some of the blood and excreted through the urinary tract. ${ }^{176}$ The third step in the concoction process took place in the individual body parts, which took from the blood the matter that they were able to appropriate. The unusable parts, destined for excretion, which resulted also during this last concoction process, either went back to the blood and were finally excreted with the urine or they left the body as imperceptible perspiration ("transpiratio insensibilis") or as visible sweat through the numerous pores of the skin. ${ }^{177}$

Each organ thus fulfilled a different function. The stomach and liver primarily served to concoct food into blood. The kidneys, spleen, bladder, skin, and bowels, on the other hand, were excretory organs first and foremost. The lungs, too, belonged to the latter insofar as they not only cooled the hot heart but also freed the body of fumes. The heart and brain took prominent positions. The heart was where spiritus vitalis was produced, while in the brain the spiritus animalis was

174 Pulz, Nüchternes Kalkül (2007).

175 Da Monte gave a good summary in his introduction to Da Monte, Lectiones (1552).

176 Cod. 11210, fol. 80v, here in the context of the theory of the origin of urine.

177 Ibid., fol. 67r. 
generated, which communicated between the immaterial soul and the body in the ventricles of the brain; they were considered the true location of the faculties of understanding. ${ }^{178}$

\section{Practical Medicine}

Learning the theoretical, natural-philosophical foundations of medicine was only one of the pillars of medical training. Medicina theorica was complemented by medicina practica. This division must not be misunderstood. ${ }^{179}$ The teaching of medicina practica was also largely theoretical and based on lectures about authoritative texts with commentary. The difference, however, was that the lectures in theoria were primarily directed at general naturalphilosophical and epistemological foundations, while teaching in medicina practica put pathology at the center, the etiology and pathogenesis of particular diseases and, based on this, diagnosis, differential diagnosis and - especially in the context of pharmacology - therapy.

In the hierarchy of the disciplines, practical professorships stood for some time below theoretical ones, something that also found expression in professors' salaries. The typical career of a successful university professor thus began with a professorship in practical medicine and led to one in theoretical medicine. Even Giovanni Battista da Monte, known today above all as a clinical teacher, followed this trajectory in Padua. In the course of the sixteenth century, however, this relationship began to reverse, indicating the effects of an overarching development that we will encounter again and again in this book, namely the growing appreciation among learned physicians of the practical knowledge and skills that were indispensable to successful diagnosis and treatment.

Handsch heard a number of lectures on the canonical texts and the specific subject areas of medicina practica. Over time, he complemented his notes on these lectures with many more notes, often based on actual experiences with patients or on what he heard from colleagues. Clearly, the foundation he acquired as a student proved helpful during his time as a physician. In 1551, for example, he attended a lecture by Vettore Trincavella on pathology as discussed in the ninth book of Rhazes's Ad Almansorem. According to Handsch's notes, which appear to relay the lecture word for word, Trincavella gave a detailed presentation

178 A good, widely quoted overview was given in the early seventeenth century by Daniel Sennert (Sennert, Institutionum (1620)).

179 Bylebyl, School of Padua (1979), pp. 337-339. 
of the different forms, causes, and treatments of headaches, palsy, tremors, and melancholy. After about 160 pages, however, Handsch's notes end with catarrh. Trincavella had not even completely covered the diseases of the head up to that point. ${ }^{180}$ To these notes Handsch added notes from lectures by Alvise Bellocati about the sections in the ninth book of Rhazes's Ad Almansoren on the diseases of the chest and abdomen. ${ }^{181}$ He also included an excerpt of notes from G. B. da Monte's lecture on pathology according to Rhazes. ${ }^{182}$ Further notes on various private lectures were included as well, for example by Fracanzano about fever, female diseases, and the morbus gallicus, as well as by Trincavella about stomach diseases. ${ }^{183}$ Nevertheless, Handsch's notes in their surviving form remain piecemeal. Systematic notes by his hand or even lectures transcribed verbatim on the entire thematic spectrum of medicina practica, on all diseases from the head to the foot and on fevers, are not extant. Possibly to make up for this lack, Handsch obtained for himself an extensive, 250-page-long transcript, which survives in his Nachlass, of a lecture given by Augustin Schurff in Wittenberg in 1537. In the lecture, Schurff covered all subjects presented in the ninth book of Ad Almansorem. ${ }^{184}$

Following Galen, learned medicine in the sixteenth century defined itself as a decidedly rational undertaking. This self-image arose not only from its basis in natural philosophy but even more so from its strict methodological approach. ${ }^{185}$ The positive experiences made by trying certain medications and other treatments on certain disease patterns might be a satisfactory basis for treatment to "empiricists", but for learned physicians who followed the Galenic motto "ratio et experientia”, it was important to be able to get to the bottom of things and recognize the cause of the complaints and the disease itself. As Da Monte and other professors advised their students, it was only in this way that the disease and its cause could be eradicated, literally pulling the disease out by the roots with a "radical" treatment; the term "radical" comes from the Latin "radix" for "root". Not getting to "root", on the other hand, meant that one was contenting oneself with merely a

180 Cod. 11226, foll. 2r-82r.

181 Ibid., foll. 149r-175v and foll. $182 \mathrm{r}-207 \mathrm{v}$.

182 Cod. 11240, foll. 9r-26r.

183 Cod. 11226, foll. 92r-119r and fol. 160v.

184 Cod. 11228.

185 Wightman, Quid sit methodus (1964). It was in this spirit that Fonseca recommended to the budding physicians in his theory of fevers to follow "prae caeteris exactissimam methodum, sine qua nihil recte vel scribi, vel operari potest” (Fonseca, Opusculum (1596), p. 4). A detailed discussion of the teaching of method and its significance for Paduan medicine can be found in Ferretto, Bassiano Lando (2006-2009) and Ferretto, Maestri (2012). On method in contemporary philosophy in general see Leinkauf, Philosophie (2020), pp. 48-81. 
"palliative" treatment, that is to say with only "cloaking" (Lat. pallium = cloak) the symptoms. ${ }^{186}$ "Palliare", as Handsch noted in this context, meant "covering up the disease for some time". ${ }^{187}$ Such a treatment would leave the real causes untouched and would not prevent the progression of the disease. As we will be seeing, a "cloaking” treatment was only indicated in certain cases, particularly for the incurable and the dying. In other cases, it was considered equal to forgoing a potentially effective therapy or even doing harm.

In this vein, Antonio Fracanzano told his students the story of a gouty patrician in Venice whose feet a lay healer had treated topically with a lotion that warmed, tightened, and strengthened the skin. The podagra disappeared. But because nature was no longer able to chase away the morbid matter from the lifesustaining parts along the usual paths, it sent it to the throat and ultimately to other body parts as well. The man first got angina and then died in the fifth year from asphyxia. ${ }^{188}$ As a physician, Handsch himself later criticized the numerous opiates that his colleague, the court physician Johann Willenbroch, ${ }^{189}$ prescribed to the sick wife of a chancery scribe. This was, in his view, not a "true" but only a "palliative" treatment. ${ }^{190}$

Because of its significance in the understanding of disease as well as its endorsement of a successful "radical" treatment, the theory of causes assumed a preeminent position in the learned medicine of the time. It was essential that the aspiring physician first learn - and this is also shown by Handsch's lecture notes from Padua - to distinguish the different categories of causes. These were first of all the external causes, the causae primitivae or procatarcticae. They included violations of the rules of a healthy way of life and other external factors that led to illness. ${ }^{191}$ Certain diseases, like consumption, leprosy, epilepsy, and the plague, Handsch learned, were transmitted by a specific contagium, which entered the body through touch or through the air, while other diseases were hereditary. ${ }^{192}$

186 Stolberg, Cura palliativa (2007), pp. 7-29.

187 Cod. 11206 , fol. $135 \mathrm{v}$.

188 Cod. 11238 , fol. $128 \mathrm{v}$.

189 So far very little is know about Willenbroch's biography (cf. the biographical sketch in Kühlmann/Telle, Frühparacelsismus, vol. 2 (2004), pp. 932-934). In his notebooks, Handsch often mentioned him as one of the physicians in his circle and both later worked together as court physicians in Ambras. Willenbroch probably came from Danzig and was younger than Handsch. He studied in Wittenberg and later in Padua. A letter dated 15 October 1586, eight years after Handsch's death, shows him still in the service of the Archduke (Universitätsbibliothek Basel, Frey-Gryn Mscr. 11, fol. 85r-v; http://doi.org/10.7891/e-manuscripta-7721).

190 Cod. 11183, fol. 483, "non praestant veram curam, sed palleativam [sic]".

191 Cod. 11210, fol. 69v.

192 Ibid., fol. 72r. 
The second category, also essential for an understanding and successful treatment of diseases, was that of the causae antecedentes or causae corporales, the immediate, bodily causes, for instance pathological humors in the body or a clogged liver. ${ }^{193}$ The distinction from the above-mentioned causae procatarcticae or primitivae roughly resembles today's distinction between "etiology", the theory of causes, and "pathogenesis", the specific pathological development and changes within the body.

More disputed was a third category, the causae coniunctae. Avicenna, as Handsch learned, used the term to describe the specific pathological changes in the body that were the immediate cause of the pathological disturbances to the natural body functions and thus of the observable symptoms. In the case of catarrh, for example, the causa procatarctica could be coldness that acted upon the head and body from the outside. A possible causa corporalis were the vapors that rose from the stomach, condensing to liquids in the head and then running off as such. These liquids, which would collect in the airways or in joints, for example, and make breathing difficult, cause a joint to swell, or other pathological changes to occur, was in this case the causa coniuncta, according to Avicenna. ${ }^{194}$ Similarly, Peter Vietor considered the causa coniuncta in the suffocation of the mother to be the harmful vapors that emanated from the underlying bodily cause, the spoiled menstrual blood that collected in the womb. ${ }^{195}$

A further, equally controversial theoretical distinction was that between "symptom", “disease”, and its "cause". Galen had attempted to delineate them clearly. All three - symptoma, morbus, and causa - were, according to him, affectus, that is deviations from the natural state of the body. ${ }^{196}$ Morbus, was the central concept. It was the unnatural ("praeter naturam") disturbance to a bodily function ("actio"). The disease was preceded by a causa, which was not, however, identical with the disease as such. Keeping company with the disease, as shadows or companions as it were, were the symptomata, whose role reflected the literal sense of the word, which comes from the Greek words for "together" and "fall" ${ }^{197}$ From his reading of Galen's De methodo medendi, Handsch took the example of a phlegmon of the foot: a phlegmon was an illness that impaired walking and its symptoms

193 Ibid., fol. 69v.

194 Ibid., foll. 69v-70r.; .

195 Vietor, De praefocatione (1610), thesis 9.

196 Galen, De morborum et symptomatum differentiis (1547), p. 80; I use a contemporary Latin translation, as Handsch and his teachers will have used it; Greek text with modern Latin translation in Galen, Opera (1822), vol. VII, pp. 42f.

197 Galen, De morborum et symptomatum differentiis (1547), p. 86; cf., Galen, Opera (1822), vol. VII, pp. 49f. 
were local changes such as redness and swelling. The bodily cause, the causa antecedens or corporalis, was identified in an overabundance of blood. The external causa procatarctica could be an excessive consumption of food. ${ }^{198}$

In abstract theory, the different types causes could be defined fairly easily. When applied to actual cases, however, the distinctions often raised questions. Pains and cramps, for example, could be painfully disruptive to bodily functions and thus could be categorized according to the outline above as diseases whose immediate causes had to be addressed. But they could also be considered the symptoms of the real disease, which could have completely different causes. In his works, Galen, not surprisingly, made contradictory statements at times, which the leading authors of the sixteenth century such as Leonhard Fuchs, Giovanni Argenterio, and Jean Fernel tried to reconcile in different ways. ${ }^{199}$

The concept of "symptoms" was particularly problematic. In his lecture notes from Padua, Handsch wrote down the overarching, general definition: the term "symptomata”, or "accidentia” in Latin, signified the pathological process, the illness as a whole. In a narrower, more specific sense, however, the "symptomata" were the actual, perceptible consequences of a disease, namely 1) the signs of abnormal sensory, motor, and cognitive faculties, 2) external physical changes perceptible by the senses such as changes to skin color as a whole or in particular regions, changes in the smell that emanated from the mouth or other orifices, or the palpable texture of the skin, for example a hardening or tightening, and 3) abnormal excretions of urine, blood, sweat, and so forth. ${ }^{200}$

In early modern medicine, the modern distinction between "symptoms" in the sense of the complaints of the patient and the "objective", externally perceptible "signs" that a physician could recognize was not yet firmly established. The subjective complaints as experienced and reported by patients ultimately also served as diagnostic and prognostic signs. Vice versa, the reddish urine which a physician found upon examination could be called a "symptom". ${ }^{201}$ According to an entry in Handsch's notebook it was primarily a matter of perspective: it was said, he claimed, that what was a "symptom" to the sick person was a "sign" to the physician. ${ }^{202}$

Particularly important and useful was the knowledge and identification of characteristic symptoms or signs, which were specific to a particular disease and

198 Cod. 11210, fol. 70r.

199 Siraisi, Disease (2002) provides a detailed account of the complex debates, presenting the different positions of selected authors.

200 Cod. 11210, fol. 72v.

201 Biblioteca comunale Aurelio Saffi, Forlì, Fondo antico, Ms. 94, fol. 39v.

202 Cod. 11210, fol. 72v, later addition. 
allowed the physician to diagnose it. They were sometimes called "pathognomic" or "pathognomonic", a term that is still commonly used today. The triad of fever, breathing difficulties, and a cough, for example, allowed for a quite reliable diagnosis of pleurisy ("pleuritis"/ "pleuresia"). ${ }^{203}$

Crucial to an understanding of the nature of each disease and to the possibility of a targeted treatment were the causae antecedentes or corporales, that is, the bodily causes in a narrower sense. As Handsch learned in Padua, these physical causes were divided into genera. There was, first of all, dyscrasia or intemperies, a deviation from the natural complexio, from the natural, individual balance of humors and qualities. Less significant deviations from the natural state that did not produce perceptible functional abnormalities were not considered diseases. According to Galen, the state of "health" was characterized by a certain range or latitude (latitudo). Pathological deviations could be either equal ("aequalis") or unequal ("inaequalis"). An equal intemperies affected all parts of the body. An illustrative example here was hectic fever, where the entire body became equally heated. An unequal intemperies was limited to certain organs or parts of the body. It could be "immaterial" or could accompany a merely qualitative change to the natural complexio of the organ or body part in question, but it could also be "material", meaning that it was caused by a pathological build-up of matter. A vivid example here was the abscess ("apostema"). Illnesses belonging to a second group were traced to the unnatural composition ("compositio") of one or more parts or organs, for example if they were too large or too small or if ducts or cavities were occluded. In everyday medical practice, such illnesses hardly played a role. The third group was composed of diseases and injuries that went hand in hand with a "dissolution of cohesion" ("solutio continuitatis"). It included for example broken bones, ulcers, torn ligaments, and other injuries which belonged first and foremost in the domain of surgery. ${ }^{204}$

\section{Bedside Teaching}

In the teaching of medicina practica, lectures, especially those about the works of Rhazes and Avicenna, had a prominent position, just as with medicina theorica. An awareness gradually emerged, however, both north and south of the Alps, that theoretical knowledge about the diagnosis and treatment of illnesses was insufficient for the aspiring physician who wanted to be successful in treating patients

203 Cod. 11183, fol. 42v, "signum pathognomicum".

204 Cod. 11210, fol. 70v-71r. 
down the road. Certainly, the learned, academic physician distinguished himself through his profound knowledge of the medical literature and was able to cite important passages from the works of Hippocrates or Galen off the cuff. He had mastered logic and methodology and was conversant in physiological and pathological theories, which could be very complex. Yet medicine was not only scientia. It was also ars, the practical application of general, abstracted knowledge to individual cases of illness. And for the successful application of theoretical knowledge, experience was indispensable. Along these lines, Johannes Brettschneider warned medical students in 1552 that "Rules alone are insufficient without plentiful practice". ${ }^{205}$ One of Handsch's student notebooks begins with the maxim, "Medicine teaches how to treat the human being [as such] but not Stephen or Peter". 206

Practical knowledge and skills were the key to professional success. It was true that because of their academic education, physicians enjoyed more of an initial reserve of trust than other healers. Erudition was esteemed by most people, not only the learned. But in both rural and urban areas, one thing counted more than anything else in the final analysis: a good reputation. It was essential that people became convinced that the physician could diagnose illnesses with accuracy and reliability and had particularly good patient outcomes to show for himself. Medical students and physicians in training were thus well-advised to gain as much practical knowledge and skill as possible, the kind that in the judgment of the day was crucial for successful diagnosis and treatment, and that, in tandem with their theoretical knowledge, would presumably guarantee their superiority over non-academic healers.

Padua, Bologna, and Montpellier were known for the high quality of their practical training. This, along with the extensive practice of autopsy was the central reason why many students from north of the Alps commenced or continued their medical studies in northern Italy or the south of France. ${ }^{207}$ By his own account, even after eight years of study, young Antonius Juncker's teachers recommended to him that he go to Montpellier, because there "better than anywhere else one sees the praxis medica, including the res simplex and the teaching of

205 Placotomus, De ratione (1552), no pagination, "nec sola praecepta sine multo usu sufficiant”.

206 Cod. 11240, fol. 3r: "Medicina docet curare hominem sed non Stephanum, Petrum." 207 Bylebyl, School of Padua (1979), p. 339. 
anatome." ${ }^{208}$ He followed the advice and studied there for a year and a half, under such professors as Guillaume Rondelet. ${ }^{209}$

The appeal of Montpellier, Padua, and other leading Northern Italian universities derived in large part from the eminence of the professors who taught medicine there. As practitioners, men like Rondelet in Montpellier, Musa Brasavola in Ferrara $^{210}$ and Da Monte, Trincavella, Mercuriale, and Capivaccia in Padua were European celebrities. Even some who were less well-known professors were valued for their good practical teaching. Explaining that he was "seeking practice" ("respiciens ad praxin"), Joachim Curaeus in 1557, for example, said he preferred Alvise Bellocati with his large practice in Padua over the young Apelatus, who was said to be very popular, especially with the germani. ${ }^{211}$

In addition to the outstanding reputation of the professors, students met with good learning conditions at these institutions. Universities north of the Alps largely confined themselves to encouraging students, through statutes and ordinances, to follow an experienced physician in his medical practice, to accompany him on his patient visits outside their regular studies. In Montpellier and at the leading Northern Italian universities, by contrast, bedside teaching was an integral part of medical training. In Montpellier as in Padua, doctoral candidates in the early seventeenth century were even required to prove their diagnostic and therapeutic skills in a bedside test with actual cases. ${ }^{212}$ Records show a similar situation in Spain in the late sixteenth century and in Padua as early as around 1530. Girolamo Amalteo recounted how he had to discuss the case of a fever patient during his exam. ${ }^{213}$

Titled Practica mea cum medicis patavinis, ${ }^{214}$ an account in one of Handsch's notebooks provides uniquely detailed information about the practical training of medical students in Padua. Other student notebooks, like that of Johannes

208 Thüringisches Hauptstaatsarchiv, Weimar, Ernestinisches Gesamtarchiv, Reg. Rr 1-316, 803, letter from Juncker, probably to Johann Wilhelm zu Sachsen-Coburg, describing his previous career, 7 December 1556; "res simplex" undoubtedly refers to the simples, i. e. to medicinal plants.

209 Afterwards he obtained a doctoral title in Valence (Archives départementales de la Drôme, Valence, D 17, list of doctoral degrees, with an entry on Juncker on fol. 7r).

210 Bacchelli, Brasavola (2008).

211 Adam, Vitae (1620), p. 205.

212 Germain, Anciennes thèses (1876), pp. 14-20; British Library, London, Ms. Sloane 727, foll. 50r-51v, G. D. Sala, Generalis casuum recitandorum forma and ibid., foll. 57r-70v, idem, Modi recitandi casus in Patavino Lycæo recepti parvulum compendium.

213 Biblioteca Marciana, Venice, Cod. lat. VII 66 (= 9684), notes by Amalteo; Clouse, Medicine (2011), p. 54.

214 Cod. 11238. 
Brünsterer from 1547-48 and of Johannes Hessus from 1552-1554, also demonstrate just how much emphasis was placed by professors and students in Padua on the acquisition of practical knowledge and skill. ${ }^{215}$ Even in their lectures, the professors took recourse to actual cases of illness so as to illustrate the practical application of medical theory to the individual patient and to provide empirical examples for the efficacy of recommended treatments. ${ }^{216}$ In his edition of the consilia and letters of his father, Bernardo Trincavella also published three of his father's lectures, each focusing on individual cases of illness. They were rather common cases: a woman with irregular menstrual periods, a melancholic young man, and a matrona who had become paralyzed following an apoplexia. In his lectures, Trincavella described the medical history or read from the written report, presumably by the attending physician, and then explained the processes taking place within the body that in his view accounted for the illness. ${ }^{217}$

Some professors even illustrated pathological theories and treatment measures using fictitious, invented cases. In his lectures on the ninth book of Rhazes's Ad Almansorem, Trincavella discussed at least four such fictitious cases, which he introduced with phrases such as: "A case is being presented. Imagine a person who ...." This was followed by a brief description of, for example, the case of a patient who lived a life of idleness and gluttony, who lost sensation in one limb, which then became paralyzed, without there having been an injury. Following this was a detailed presentation of the indicated treatment. ${ }^{218}$

An innovative teaching format that appears to have been developed in Padua at the time received particular attention among contemporary observers: the socalled collegia. Referred to occasionally as consultationes, the collegia presumably developed from the common practice of physicians consulting jointly about a patient, orally or in writing. Students highly valued this form of instruction and took detailed notes. Their notes on collegia were sometimes printed in collections of consultationes and consilia. ${ }^{219}$ As a result, some historians have confused them

215 Universitätsbibliothek Erlangen, Ms. 911 (Brünsterer) and Ms. 910 (Hesse).

216 E.g. Cod. 11006, fol. 150v, note on Bellocati's story of his successful treatment of dropsy. 217 Trincavella, Consiliorum (1586), foll. 105v-111v; Trincavella's comments on these three cases are explicitly marked as "lectio" and Trincavella addressed his listeners directly with words like "you have heard" ("audivistis"); on Trincavella's consilia see also Tanfani, I consilia medica (1952).

218 Cod. 11226, foll. 2r-82r, here foll. 50r-51v: "Proponatur casus. Sit aliquis qui patiatur paralysi”; similarly ibid., foll. 72v-74r: "Proponatur casus. Sit aliquis, qui patiatur epilepsiam per essentiam a capite et inquirat praeservationem."

219 Thus, in his preface to Da Monte, Consultationum (1565), Johannes Crato wrote of the “consultationes”, which were commonly called "collegia” ("quae vulgo collegia appellantur”); for example, Trincavella, Consilia (1587) documents numerous collegia with the respective 
with epistolary consultations, but this was a very different genre. ${ }^{220}$ During a collegium, several professors would come together and discuss a particular case of illness in front of students. First, one of the professors would introduce the medical history orally ("audivistis historiam") or based on a written report ("exhibita charta"), which was read aloud. Following this, he and the other professors in attendance would present their assessment one after the other. From the complaints that had been described and possibly from the externally visible signs of illness, when the patient was present, they would conclude which pathological processes were taking place within the body and which remedies were best suited to combatting the causes of the illness and healing the disease. ${ }^{221}$

This reviewing of cases in a shared and structured manner in front of congregated students, with professors presenting their case evaluations in turn, clearly was a very efficient didactical method, one that might in fact even be worth reviving in present-day medical teaching. Students were presented with actual cases of illness and learned the methodological approach that was to be followed at the bedside - how they were, as Vettore Trincavella put it, to arrive at an understanding of the hidden from what was manifest to the senses, ${ }^{222}$ and so how to identify pathological changes within the body from signs and symptoms and to come to therapeutic conclusions. At the same time, students experienced how, depending on the illness and the case, even the assessments of famous luminaries could significantly diverge from one another. And all the while they were gaining a skill that would be crucial in dealing with noble patients, assuring their professional success: the ability to distinguish oneself by convincingly presenting a well-founded assessment at the bedside during a joint consultation with other physicians present.

statements of Trincavella, Fracanzano, Falloppia, Bellocati, Frigimelica and other Paduan professors.

220 Treating the oral statements of Da Monte and Capivaccia recorded by their students like written consilia, because they were published under titles such as "consultationes" and "consilia”, Monica Calabritto has argued for a substantial transformation of the genre of the written consilium since the Middle Ages (Calabritto, Curing (2012)). However, these differences are clearly due to the difference between written consilia and student notes on the professors' oral pronouncements.

221 E.g. "Collegium habitum de muliere laborante cancro in dextra mamilla", with statements by Gabrielle Falloppia, Francesco Frigimelica, Vettore Trincavella and two other professors, 10 April 1552 (Universitätsbibliothek Erlangen, Ms. 910, foll. 50r-53r); the manuscript contains notes on a whole series of collegia as well as copies of various consilia, among others by Pietro Andrea Mattioli.

222 Trincavella, Consilia (1587), col. 266. 
The collegia and the casuistic elements that came to bear in lectures were perfectly suited to teaching aspiring physicians the cognitive and argumentative skills that they would need later in practice. They imparted the systematic, methodological-analytic approach that would make it possible to recognize the true causes of disease within the body and thus to attack the disease at its roots. They pointed the way to "rational" methodological medicine, which served learned physicians as a means to distinguish themselves from the "empiricists" whose knowledge was purely experiential. But without a patient present, students could only acquire the practical, sensory, physical, and manual skills needed at the bedside to a very limited extent - skills that could determine a physician's success or failure. Without seeing what the patient looked like, it was difficult to determine his or her temperament, and they had no opportunity to ask the right questions, to inspect excretions, to examine the patient with their own hands if need be, or to adapt treatment as his or her condition changed in the course of the disease.

Padua, Montpellier, and other Northern Italian universities offered excellent conditions for the acquisition of such practical skills. Before all other "innovations in the study of medicine", contemporaries already extolled the "exceedingly praiseworthy practice" at Italian universities of discussing the nature, causes, and treatment of illnesses with students at the bedside ("circa aegrorum lectulos"), that is, during shared patient visits. ${ }^{223}$

This practice of bedside teaching has received a great deal of attention in historical research, undoubtedly also because of the preeminent significance of clinical teaching in modern medical training. Older generations of historians traced the beginnings of systematic teaching at the bedside to seventeenth-century Leiden, Netherlands - until evidence was found that Leiden was modelled on the much earlier example of Padua, in turn, where Dutch medical students had experienced it. $^{224}$ In Padua, already in the 1540s Giovanni Battista da Monte had taken his students with him on patient visits in the Ospedale di San Francesco. Unlike many other hospitals of the time, especially those north of the Alps, which served primarily as care facilities for the impoverished elderly, the infirm, or the otherwise needy, major hospitals in Northern Italian cities also provided

223 Solenander, Consiliorum (1609), preface to the students, "de aegrotis confabulationes quaedam, quales in visendis aegrotis solent inter medicum et discipulos haberi: qui Italiam vidit, novit morem hunc laudatissimum, quo sane cunctas alias nationes in studio medico antecedit”); similarly Trincavella, Consilia (1587), dedicatory epistle of the printer C. Waldkirch to Petrus Severinus, 1 April 1587.

224 For a detailed summary of the development of bedside teaching in Leiden see Beukers, Clinical teaching (1989). 
medical care in a stricter sense. ${ }^{225}$ For some 200 years, da Monte came to be considered the "inventor" of clinical teaching in Western medicine. ${ }^{226}$ In recent times, some authors have once again cast doubt on this assessment, however. From their analysis of the sources, they have arrived at the conclusion that Da Monte only seldom taught at San Francesco, and when he did it was not because he was actively seeking the opportunity to teach in this way but because physicians at the hospital had called him. They concluded that there was no evidence that any systematic clinical teaching was going on. ${ }^{227}$

These doubts are unfounded, however. ${ }^{228}$ Merely reading the various volumes of Da Monte's Consilia shows there were at least two dozen consultations at the hospital which were written down by students who participated in them, and we may assume that there were many more. Da Monte's Consilia alone mention ten visits with a consumptive patient with an empyema, a collection of pus in the lung, ${ }^{229}$ and six with a febrile, dropsical boy. Da Monte dictated a consultation with a boy with scabies "at the hospital, during the sixteenth visit". ${ }^{230}$ In a different consilium, a seventeenth bedside visit is documented, a call on a clergyman who was once ill with the French disease but was now suffering from the effects of mercury poisoning. ${ }^{231}$ According to the student notes, Da Monte connected the bedside teaching with lectures. In his discussion of two patients with pseudotertiana during his last teaching rounds in 1543, he explicitly stated his intention of linking what he taught that day from the lectern with that which manifested itself in the patient. ${ }^{232}$

It seems that Da Monte was not the only one to take his students with him on clinical rounds and, as Handsch's notes clearly show, these rounds remained an established practice in Padua after Da Monte's death in May of 1551. Lorenz Gryll, who studied for almost two years in Padua, with Da Monte and Landi, later recounted how he went to the hospital in Padua with Antonio Fracanzano every day

225 Henderson, Renaissance hospital (2006).

226 Comparetti, Saggio (1793); Rasori, Sul metodo (1808/1809), pp. 58-62.

227 Orsolato, Prima fondazione (1872-73), pp. 127-152; Ongaro, L'insegnamento clinico (1994), pp. 357-369.

228 On the following, see my detailed account in Stolberg, Bedside teaching (2014).

229 Da Monte, Consultationum (1565), coll. 455-461, "De empyico et phthisico in hospitali, visitationes decem".

230 Ibid., col. 885, "in hospitali, in XVI. accessione".

231 Ibid., coll. 867-869: "Haec cura facta fuit [. . .] in decima septima visitatione hospitalis, quae dedit occasionem octo lectionibus de morbo Gallico"; it is not clear whether the visits took place in the same year as the above-mentioned sixteenth visit.

232 Ibid., col. 938 (wrongly paginated as 638): "Ut continuemus ea quae docemus in cathedra, cum iis quae apparent circa aegros, non abscedemus ab iis quae diximus hodie.” 
at a certain hour, where he witnessed the treatment of innumerous patients. ${ }^{233}$ Along the same lines, Handsch claimed that he "went with the physicians to see the sick people at the hospital nearly every day, where, on many a day, one observed up to thirty urines." ${ }^{234}$ He recorded, in particular and at times in great detail, cases he saw in the hospital with Antonio Fracanzano, highlighting some of his entries with headings such as "Among the patients of Doctor Fracanzano at the Hospital of San Francesco" or "A few things that I saw at the hospital with Doctor Fracanzano”. ${ }^{235}$ Like Da Monte, Fracanzano paired his bedside teaching with lectures. Handsch filled about twenty-five pages just with his notes on a lecture ("lectio") about uroscopy, which Fracanzano had given at the hospital. ${ }^{236}$ A visit with a patient with a raw, altered voice who was experiencing asthmatic complaints and who thought he was bewitched even gave Fracanzano the opportunity to speak at length about conjurations and inflicted illnesses and about evil women who harmed others with dried menstrual blood. ${ }^{237}$

Whether the Ospedale di San Francesco was the first place in Europe where students received clinical instruction at the bedside is a different matter. At about the same time, the cases of various hospital patients in Bologna were also captured in the student notes that served as the basis for the Processus, curationes et consilia of Elideo Padovani (aka Helidaeus Padovanus, d. 1575). Mention is made, for example of a "paralytica in hospitali", of two dropsical patients at the hospital who, according to Padovani suffered from a hardening or occlusion of the spleen, of a man "in hospitali" with an occluded and hardened spleen and there is an especially elaborate description of a "pleuritico in hospitali". Students took note of the prescriptions that Padovani made on six different days - and thus, by all appearances,

228 On the following, see my detailed account in Stolberg, Bedside teaching (2014).

229 Da Monte, Consultationum (1565), coll. 455-461, "De empyico et phthisico in hospitali, visitationes decem".

230 Ibid., col. 885, "in hospitali, in XVI. accessione”.

231 Ibid., coll. 867-869: "Haec cura facta fuit [. . .] in decima septima visitatione hospitalis, quae dedit occasionem octo lectionibus de morbo Gallico"; it is not clear whether the visits took place in the same year as the above-mentioned sixteenth visit.

232 Ibid., col. 938 (wrongly paginated as 638): "Ut continuemus ea quae docemus in cathedra, cum iis quae apparent circa aegros, non abscedemus ab iis quae diximus hodie.”

233 Gryll, Oratio (1566), fol. 4r: "Cum Antonio autem Francazano [sic] quotidie stata hora in Xenodochio Patavino, crebris, varijs et prope infinitis curationum exemplis interfui”.

234 Cod. 11206, fol. 26r.

235 Cod. 11238, fol. 119, "inter patientes D. Frankenzani in hospitali S. Francisci” (Handsch later added "anno 1551 et 52"); ibid., fol. 127r: "Pauca quae vidi in hospitali cum D. Frankenzano in vere anni 1553”.

236 Cod. 11240, fol. 151r-v and foll. 80r-92v.

237 Ibid., fol. 120v. 
on six different visits. ${ }^{238}$ These medical rounds may well have taken place before Da Monte introduced the practice in Padua around 1542. Padovani received his medical doctorate in Bologna already in 1535 and cases he treated outside of the hospital are documented already for the year $1540 .{ }^{239}$ Pieter van Foreest, who studied in Bologna from 1540 to 1543, furthermore gives an account of a kind of outpatient clinic at the hospital during that time. He describes how Padovani in the presence of students gave medical advice to the large numbers of country people who came with their urine to the local Ospedale della Vita. ${ }^{240}$ There is so far no conclusive evidence that Padovani was a professor at the university. He may have been employed as a hospital physician. ${ }^{241}$ In the title of Johannes Wittich's edition of Padovani's Consilia, he is explicitly called a "professor", however, and the medical students who accompanied him are mentioned. The volume also contains various lecture-like texts in which the author, as was typical for lecture notes of the time, spoke of himself in the first person and addressed his audience in the second person. Moreover, a manuscript in the Biblioteca comunale in Cesena, contains three treatises bei Elideo Padovani, on the diseases of women, on the diseases of children and on the simples. ${ }^{242}$ All this strongly suggests that he was, to some degree at least, involved in formal university teaching. ${ }^{243}$

There is also another reason why some restraint needs to be practiced with respect to the eulogies sung for Da Monte as the "inventor" of bedside teaching: the professors did not need a hospital to do their bedside teaching. Most sick people were treated not at the hospital but at their own home. Professors of medicine commonly had their own larger or smaller private practices, and they allowed their students to accompany them on their house calls. When they walked down the street surrounded by a sizeable group of students, this even redounded to their honor and polished their reputation. Thus the opportunity frequently arose for aspiring physicians to watch experienced practitioners on the job, and this

238 Padovani, Processus (1607), p. 16, p. 137, p. 143 (wrongly paginated as 431) and p. 72; further hospital cases on p. 103, p. 141, p. 208, and p. 215.

239 Dondi, Elideo Padovani (1951); idem, Cenni (1975); Fantuzzi, Notizie (1788), pp. 215-218; Biblioteca comunale Aurelio Saffi, Forlì, Fondo antico, Ms. 94, fol. 7r, fol. 17r, fol. 39v, fol. and 59r (patients treated by Padovani in the spring of 1540).

240 Foreest, Uromanteia, p. 229; according to Mauro Guarino, students in Bologna regularly visited patients in the Ospedale della Morte with their professors in the fifteenth century already (Guarino, Profilo storico (2005), pp. 77-93, here p. 79); unfortunately, he does not indicate his source.

241 Dondi, Elideo Padovani (1951), pp. 139-144.

242 Biblioteca comunale, Cesena, Ms. 167-29.

243 Padovani, Processus (1607). 
practice appears to have been routine at leading Italian universities in the sixteenth century. $^{244}$

House calls provided an especially good opportunity for comprehensive instruction that was literally "clinical”; the Greek work "kline”, after all, simply means "bed". At the hospital, as was doubtlessly advantageous, professors and students could visit several patients during a single call and thus could gather experiences with different disease patterns more quickly. House calls, on the other hand, allowed for a closer observation of patients' life circumstances and habits, which medicine at the time deemed of major significance when establishing the origin and development of illness. In the process, students also learned from their role models how to interact with those wealthy, upper-class patients whose endorsement and patronage would later determine their professional and economic success in their own medical practice.

In Padua, the conditions for training during house calls were quite favorable. Just within the town itself with its approximately 5,800 houses (1554), ${ }^{245}$ there was a considerable number of potential patients. Moreover, Venice, one of the largest cities in Europe at the time, was not far away. In their notebooks, Handsch and Brünsterer recorded dozens of patients they saw, accompanying their professors. Quite frequently, they visited the same patient a number of days in a row, meaning that they were able to follow the course of the disease and observe the success of the treatment. Handsch mentioned, for example, two house calls by Gabrielle Falloppia to a child who had accidentally drunk poison, and further visits to a patient with the French disease. It appears it was common for medical students to come under the tutelage of a certain professor or at most two. In the case of Brünsterer it was Alvise Bellocati, and Lorenz Gryll also followed Bellocati, "in practice, as they call it, for several months throughout the town". ${ }^{246}$ Handsch saw numerous patients with Fracanzano and Trincavella. As various entries in Handsch's notebooks make clear, these house calls also offered a welcome opportunity to discuss each case and the disease in question with the professor. ${ }^{247}$

A manuscript I recently discovered in Forlì documents the same practice for Bologna, for the years from 1540 until 1543. ${ }^{248}$ An unknown writer described in considerable detail the cases of almost a hundred patients he saw with his

244 Rath, Entwicklung (1965), pp. 8-10; Fichtner, Padova e Tübingen (1972-73), here p.54; Bylebyl, School of Padua (1979), p. 339.

245 Brugi, Gli scolari (1903), p. 12.

246 Gryll, Oratio (1566), fol. 4r.

247 Cod. 11238 , fol. 128v.

248 Biblioteca comunale Aurelio Saffi, Forlì, Fondo antico, Ms. 94; the manuscript carries the title, in handwriting, "Curationes variae di Alessandro Padovani". This title is clearly 
“teacher” ("praeceptor”), the Bologna professor Benedetto Vittore (Benedictus de Victoriis, Benedetto Vettori, d. 1561). Frequently they paid a whole series of daily or twice daily visits to one and the same patient. Sometimes other physicians were involved in the treatment as well and the writer learnt about their approach and their remedies - the writer mentions among others Matteo Corti (aka Curzio, 1475-1542/44), Elideo [Padovani], Lodovico Vitali (d. 1554), Jacopo Pacini (d. 1560), Virgilio Gherardi (d. 1541), and Antonio Maria Betti (d. 1562) who treated patients together with Vittore or before Vittore was called in. Occasionally, the writer also indicates that he himself took care of patients, before he consulted Vittore or the patient called him. The notes focus on the treatment and, in particular, on the professors' recipes, which the writer probably hoped to use later himself, on his own patients. He also describes, however, how they examined a patient's urine, blood or excrements together and how Vittore palpated a patient's liver. ${ }^{249}$ At times, Vittore seems to have turned patient visits into an opportunity for more elaborate explanations. In the case of a 33-year-old patient, for example, he pointed out "the manifest signs, from Galen and others" (which showed that the young man suffered from consumption, which a colleague had doubted) and listed the four "intentions" ("intentiones") which guided his treatment, targeting the patient's pulmonary ulcer, his fever, his cough and his catarrh respectively. ${ }^{250}$

In Ferrara, where Handsch would later receive his doctorate, we find a similar situation. A manuscript that appears to have been composed by different medical students or physicians in training contains detailed notes on the cases of illness that were observed in Ferrara, in the 1540s, by one or several medical students or young physicians when they accompanied Antonio Musa Brasavola,

erroneous, however, and was added later. The manuscript has survived among the documents of the physician Alessandro Padovani (d. 1637) but many of the entries in this manuscript carry a precise date, starting in February 1540. The writer does not indicate whether other students or budding physicians were with him. There are altogether 101 cases. Vittore treated 96 of them, alone or with others. The notes on four cases only mention Matteo Corti and in one case we hear of the treatment by a certain Hieronymus de Lageris. The large majority of cases, as far as they are dated, occurred between the spring of 1540 and the spring of 1543. Three entries carry later dates, namely 2 February 1547 (addition to a previous, undated note) and 1554 (a case initally treated by the writer) and 22 April 1555 (on Vittore's treatment of a woman with suffocation of the womb); they were by all appearances added later on pages that had remained empty, at the beginning, before the index, and on the last page.

249 Ibid., fol. 97v, "vidit bis urinam"; fol. 22r, "vidit sanguinem colericum et adustum nigrum”; ibid., fol. 20r, "inspexit excrementum"; ibid., fol. 87r, "tetigit tumorem".

250 Ibid., fol. 82v-84v, 9 November 1541; “demonstravit per indicia manifesta ex Gal[en]o et ex aliis". 
Antonio Maria Canani, Domenico Bondi, and Luca Riccardo on their visits to patients. Sometimes they even visited the same patient twice on the same day. ${ }^{251}$

In Paris, too, it was normal for the baccalaurei of medicine to come under the tutelage of a professor and accompany him on his house calls. ${ }^{252}$ Professors in Montpellier invited or asked their students to accompany them on visits. In the early seventeenth century, Regensburg physician Strobelberger was emphatic in his praise for the practical "exercises" in Montpellier which he had experienced himself. In the town and in the hospitals, according to his account, students had the opportunity to visit sick people, ask them questions, and hone their skills at performing uroscopy and pulse diagnosis. In German countries, by contrast, he complained, students were not allowed to join their teachers at the bedside but had to stay outside. ${ }^{253}$

So far, little evidence has been found of regular bedside teaching in German-speaking areas during the sixteenth century. At the university in Tübingen, the statutes stipulated that students were to accompany their teachers on patient visits, but it remains questionable whether this was ever put into practice. ${ }^{254}$ Of course, bedside instruction may simply not have been put on record at universities with few medical students because the professor could easily take individual students with him when he visited patients. This was especially true if students, as was often the case, boarded with their professors or at least dined with them. Soon after devoting himself to medicine in Wittenberg, Simon Wilde regularly dined at the table of Georg Curio in his house and could thus hope to accompany him on his sick visits. Curio did in fact take him along for several days "on his practice" when he travelled to the court of the Prince of Anhalt. ${ }^{255}$ And in the extensive medical notes written by a student of Jodocus Willich in Frankfurt on the Oder in the 1550s, there are also a number of entries

251 Biblioteca Ariostea, Ferrara, Collezione Antonelli, Ms. 531, “Curationes Antonij Musae Brasavoli"; the title was probably added at a later point; on this manuscript see Menini, Curationes (1952) and Pomata, Sharing cases (2010), pp. 208-211. A number of entries are dated but without indicating the year. Occasionally the day of the week is given, however, (e.g. "Die lune 13. Aprilis") from which we can conclude that visits took place in and around 1545 or in and around 1551 - only in those two years April 13 fell on a Monday. Since an entry towards the end of the manuscript, which is written in the first person and apparently documents the beginning of the writer's own medical practice, is dated April 1547, the visits to the sick documented in this manuscript most likely took place in or around 1545.

252 Lunel, Maison (2008), p. 40.

253 Strobelberger, Laureationum medicarum (1628), p. 18.

254 Kuhn, Studenten (1971), p. 36.

255 Buchwald, Simon Wilde (1894), pp. 73-75. 
on the way in which Willich treated a certain patient, suggesting that the unknown author had been with him at the bedside. ${ }^{256}$

Clear indications of systematic practical teaching by professors have so far only been found for the Northern Italian universities and Montpellier. Even there, some students would take time off to enhance their practical knowledge or would use the long summer holiday to work with a physician outside the university and gain practical experience and perhaps even treat individual patients on their own. Handsch mentions quite a few cases that he saw in the summers of 1551 and 1552 with the Padua professor for medicina theorica Comes de Monte (?-1587) also known as Panfilio (or Pamfilio) Pigatti - not to be confused with the more famous Giovanni Battista da Monte - in Comes de Monte's hometown of Vicenza. ${ }^{257}$ According to his own account, Andreas Vesal treated patients in Venice under the guidance of the most well-known professors there. And J. C. Monnet, too, used the Padua university's summer break to go to Venice, where he could observe medical practice and could practice treating patients himself in individual cases ("in singularibus"). ${ }^{258}$ In Montpellier it was even expected that physicians in training would spend at least half a year working with an external physician to gain practical experience. ${ }^{259}$

Patient visits with professors - more than the case studies treated in lectures and the discussion of individual cases in the collegia - provided aspiring physicians with the knowledge and skill that they would later need in their medical practice. This is where students learned how to apply their theoretical knowledge to a specific case of illness, how they were to recognize from the symptoms and signs as well as from patient history the nature and causes of the illness in question. Based on this they furthermore learned what kind of treatment they were to prescribe, and here they also took the way of life and the temperament of the patient into consideration. But more than this, they learned to

256 Medical Historical Library, Yale University, New Haven, c. 1552, not inventoried; on the cover, the initials "I. M. D." are written. I have not yet been able to identify the author. Since the "D" most likely stands for "doctor", the first name probably began with an "I" or a "J" and the last name with an "M", which was very common combination of initials at the time.

257 Cod. 11238, foll. 115r-118v, "Aliquot observationes ex praxi D. Comitis de Monte Vicentini, Vincentiae factae in mense Augusto et Septembri Anno 1552", apparently continued on foll. 70r-74v and, under the explicit title "Ex praxi D. Comitis de Monte observata", on fol. 124r-v. Little is known about Comes de Monte, who gave up his professorship in 1554 and returned to Vicenza (biographical sketches in Santa Maria, Biblioteca, vol. 4 (1772), pp. CXXVI-CXXXVI, and Mantese, Storia (1969), pp. 66-71); he published an edition of Alessandro Achillini’s Opera (Achillini, Opera (1545)).

258 O’Malley, Andreas Vesalius (1965), p. 75; Monnetus, Ad lectorem (1554).

259 Dulieu, La médecine (1979), p. 63. 
ask the right questions, and they learned to sharpen their perception, which was only possible with the patient in the room. While it was possible to communicate orally or in writing about a patient who could not be seen by a physician, this indirect communication was a poor match for the sensory perception that was possible when a physician attended a patient, observing his or her body and its changes and making the diagnosis.

Just looking at the sick person's body could supply valuable clues. The color of the skin and hair, the person's girth, the width of the chest, bulging veins, and similar signs were helpful in determining a patient's temperament or complexio. Certain pathological changes were also readily visible to the naked eye. Sometimes they were pathognomic, so indicative of certain illnesses that is that they alone were enough to make a diagnosis: swollen stomachs or extremities, for example, for dropsy; red patches, pustules, and other skin conditions for certain fevers; or tumors under the skin, at times ulcerating, for cancer.

The physical presence of the patient was especially important if not indispensable for physicians in training who wanted to learn and practice the three most important diagnostic procedures of the day: uroscopy - insofar as the finding was to be compared with the physical constitution of the patient - and, more so, pulse diagnosis, and palpation, especially of the abdominal area.

Handsch took lengthy notes from a lecture about uroscopy given by Antonio Fracanzano at the hospital. ${ }^{260}$ The performance of uroscopy required more than extensive knowledge, however. It took practice. From Handsch's notes we learn, that, according to G. B. da Monte, some were so skilled at uroscopy that they were able to say amazing things ("miranda") after having examined urine. ${ }^{261}$ For this reason, Handsch repeatedly complemented his notes with practical tips given by Da Monte and other professors in their lectures or during patient visits. The urine of an old woman, for example, whom Handsch had visited with Trincavella in November of 1551, was of a "good" consistency with "praiseworthy" sediment and a barely visible cloudiness in the middle. The coloration, however, was more intensive than was to be expected with a woman whose vital heat was necessarily weakened due to age. The darker coloration alone, then, was enough to diagnose a fever according to Trincavella. ${ }^{262}$

If a patient was visited several times or even daily, as was common with both house calls and hospital consultations, students furthermore had the opportunity to observe the variation in the urine of one and the same patient. They were able

260 Cod. 11210, foll. 80r-92v; according to a note which Handsch added later (ibid., fol. 80r), Fracanzano lectured again on the topic the following year.

261 Ibid., fol. 80r.

262 Cod. 11238, foll. 95r-96r. 
to follow the changes and the course of the disease and sometimes the success of the treatment. Johannes Brünsterer wrote in his notes, for example, that the urine of a sick teacher was cloudy and reddish on the first day. Brünsterer had made several visits to the patient with Alvise Bellocati in October 1547. On the second day, the urine was greenish and at the bottom of the flask a very raw substance had collected. In keeping with the dominant conception, it was there that the morbid matter could be presumed to reside. The patient gradually felt better and the urine was less cloudy, something Bellocati interpreted as a sign that the nature of the patient had successfully evacuated the morbid matter over the past days. ${ }^{263}$ Similarly, Handsch in his student notes described the changes in the urine of a young man with putrid fever whom he visited a number of times with Trincavella. At first, the urine was copious and thick and not particularly reddish, with whitish residual matter at the surface, which, however was blown apart by winds ("ventositates"). The following day the visible matter was more homogenous. On the third day, the two men saw the plentiful material lying in a circular shape at the bottom of the matula, looking like a thick cloud. According to Trincavella, if a disease was receding, this manifested itself in this way as nature began to separate out the burnt, ashen parts that had been produced during the putrefaction within the body. In the case at hand, however, the patient's condition deteriorated and he died. ${ }^{264}$

The urine could be examined in the patient's absence if necessary although in this case some important diagnostic clues might be missed that could be taken from his or her external appearance or from the answers to the physician's questions. The patient's presence was essential, however, during diagnostic procedures that relied on the sense of touch. Determining the qualities of the pulse and recognizing the subtle differences so as to draw the correct diagnostic, prognostic, and therapeutic conclusions was notoriously difficult and required a great deal of experience. Pulse diagnosis did not mean counting the number of beats during a given period of time with the help of a clock; such quantification gained importance only centuries later. Even in the simplified form that Da Monte taught his students, at least four central characteristics had to be determined: 1) the size or amplitude ("parvus", "magnus"), 2) the speed ("velocitas"), with which the individual beat reached its greatest expanse, 3) the frequency, i.e. whether the individual beats followed fast or slow upon each other, and 4) the evenness ("aequalitas"), which could be disrupted by pauses or

263 Universitätsbibliothek Erlangen, Ms 911, pp. 1-2, p. 11 and p. 14.

264 Cod. 11238, foll. 96r-97v; shortly afterwards, he noted the urine findings he encountered during various visits to a woman with tertian fever (ibid., fol. 99r-v). 
additional beats. Some authors added further characteristics like the "strength", as measured by the force the physician needed to use to stifle the pulse.

The pulse could thus be described in great detail and diagnoses were accordingly differentiated. Da Monte, for instance, found that the pulse of a severely ill febrile and dropsical patient was hard, like a taut bow, and because of the hardness the frequency ("frequentia") was far more pronounced than the speed ("velocitas"). ${ }^{265}$ The physician, then, had to draw the right conclusions from his characterization of the pulse, which he tried to make as precise as possible. Above all, he had to consider the vital force, the vital heat, and the movement of the vital spirits whose periodic passage in the arteries was responsible for the palpable pulse according to the dominant medical teachings. ${ }^{266}$ In the case just mentioned, it was important to decide whether the hardness of the pulse originated from the great load in the vessels ("ex materia") or from the strength of the driving force ("ex virtute"). ${ }^{267}$ At a different occasion, Da Monte taught his students that a weak and fast pulse indicated grave danger for life and limb. ${ }^{268}$ Fracanzano, too, was very pessimistic about such cases. ${ }^{269}$

Professors encouraged their students to gain experience in the art of pulse diagnosis. Da Monte, for instance, visiting a patient with empyema and consumption with students, explained that the patient's pulse was quite small. "If you haven't grasped this yet, practice with your hand and reason so that you can grasp it". ${ }^{270}$ About one of his sick visits with Fracanzano, Handsch noted, "He had me feel the pulse". ${ }^{271}$ At such opportunities, students also learned practical tricks: "Always speak with the patient when you feel the pulse", Handsch noted, for example. This would soothe the patient and help ensure that the pulse was not changed by the patient's fear and thus that the diagnosis was not distorted. ${ }^{272}$

The third, central diagnostic skill that had to be acquired and that likewise involved the aspiring physician's senses was the physical examination of the patient. This claim may seem surprising at first glance. Until very recently, researchers in the history of medicine claimed that early modern physicians

265 Da Monte, Consultationum (1559), p. 555.

266 Handsch also pointed out the alternative explanation that the arteries pulsed on their own thanks to their vis vitalis (Cod. 11224, fol. 155v).

267 Da Monte, Consultationum (1559), p. 555.

268 Da Monte, Consultationum (1565), col. 460.

269 Cod. 11238, fol. $127 \mathrm{v}$.

270 Da Monte, Consultationum (1565), col. 460: "Si haec nondum deprehendistis, exercete manum et mentem, ut possitis deprehendere."

271 Cod. 11238, fol. 128r.

272 Ibid., fol. 121r. 
physically examined their patients only seldom or not at all. ${ }^{273}$ Handsch's notes give us a completely different picture, however. Even as a student, he described numerous occasions when he saw his teachers put their tactile sense to use. Just touching the patient could unearth important diagnostic and prognostic clues. In the case of fevers, the skin was hot. Excessive coolness could be an indication that the vital heat was dying down: the inner heat and the vital spirits were retreating to the inside. Thus Bellocati, according to Brünsterer's account, saw how poorly an old woman was doing when he touched her cold extremities, and also felt her weak pulse. She died the next day. ${ }^{274}$

In medical practice, but also in medical teaching, the physical examination of the abdomen in particular played a central role. Handsch repeatedly described how his teachers examined patients with their own hands and showed their students how to diagnose properly on the basis of manual examination. He wrote, for example, "He touched the area of the liver" when describing a patient visit with Trincavella, who suspected a blocked spleen, "and in one part it was harder and in another part softer". ${ }^{275}$ In the case of a female patient, Trincavella diagnosed an obstruction of the spleen after having touched the upper abdomen ("tetigit [. . .] hypocondria"); he later specified his diagnosis: the issue was scirrhus, a hardened tumor of the spleen. ${ }^{276}$ The famous physician Vesal - this Handsch heard from Falloppia - had ridiculed those who wanted to learn the constitution of the spleen through palpation as the spleen lay too deep within the body. Falloppia countered this by saying that this was only true of healthy people, thus exposing Vesal's lack of clinical experience. An obstructed, hardened spleen, he continued, could be very large and weigh many pounds. ${ }^{277}$ Francesco Frigimelica (1491/ 92-1558) $)^{278}$ and Fracanzano too, examined their patients in this way in the presence of their students and sometimes repeated the examination at the next visit. In his account of Fracanzano's examination of a patient with pleurisy Handsch wrote, "He palpated the liver and then the ribs". ${ }^{279}$ In the case of Fracanzano's

273 Porter, Rise (2004); see, however, my detailed analysis in Stolberg, Examining the body (2013).

274 Universitätsbibliothek Erlangen Ms. 911, p. 3.

275 Cod. 11238, foll. 98v-99r.

276 Ibid., fol. 89r.

277 Cod. 11210, fol. 4 r.

278 Cod. 11183, fol. 51v and fol. 106v; Frigimelica taught in Padua first on medicinal plants and then, since 1532, on theoretical and practical medicine (Riddle, Three contributors (1979), p. 148-150; Ongaro, Medicina (2001), pp. 173f.).

279 Cod. 11183, fol. 123v: “Tangebat hepar et deinde costas”. 
examination of a young Englishman with a persistent fever he noted, "He palpated the upper abdomen". ${ }^{280}$ When he accompanied Comes de Monte on his house calls in and around Vicenza, Handsch also saw how his teacher examined patients' abdomens with his hands. This was, as Handsch put it, common practice. ${ }^{281}$

Students were more than observers in these situations. They were allowed to literally try their hand at manual examination, at palpation, especially of the abdominal area. When Fracanzano felt for the spleen during a sick visit and said it felt hard and swollen, he also gave Handsch the opportunity to examine the patient. Unfortunately, Handsch felt nothing. ${ }^{282}$ Student notes on Da Monte's teaching also repeatedly refer to cases involving diagnosis from palpation. They show beyond any doubt that patients' abdomens were frequently examined with the hands. In retrospect, it is difficult to determine how often this happened in the presence of students. In any case, Da Monte emphasized the significance of palpation and the findings that come from it, and taught students to correctly assess them. In the case of a young man, for instance, he diagnosed a pronounced hardening of the spleen, which could almost be called a scirrhus, and similarly in the case of a Milanese clergyman, he diagnosed a very hard and enlarged spleen. ${ }^{283}$ His findings in the case of an unnamed patient from the higher nobility were especially detailed: what was initially very striking was a tenseness in the right upper abdomen in the stomach region, in the area of the false ribs. If one pressed lightly in this area, the patient felt only slight pain, but it became stronger the harder one pressed. In addition to this there was a tension in the entire abdominal area. ${ }^{284}$

It was not in Padua alone that students were introduced to physical examination, to the palpation of the abdomen. In Ferrara, Da Monte's teacher Musa Brasavola likewise examined patients with his own hands in the presence of students. In the case of a patient with lung empyema, for example, he found a collection of pus in the lung, a hardening in the liver area and, more importantly, in the area of the spleen. He also pressed with his fingers on the patient's lower ribs, which caused intense pain. ${ }^{285}$ Students also documented a manual examination performed by Elideo Padovani in Bologna on a woman who believed she was

280 Ibid., fol. 129r, "tetigit hypocundria [sic!]” .

281 Ibid., fol. 125v, "ut mos est".

282 Ibid., fol. 130v, "ego tangens nihil sensi”.

283 Da Monte, Consultationum (1554), p. 304 and p. 361.

284 Ibid., 370.

285 Biblioteca Ariostea, Ferrara, Collezione Antonelli, Ms. 531, fol. 17r. 
pregnant. Her womb had felt enlarged for the past ten months. On the basis of palpation, Padovani concluded that there was a collection of fluid. ${ }^{286}$

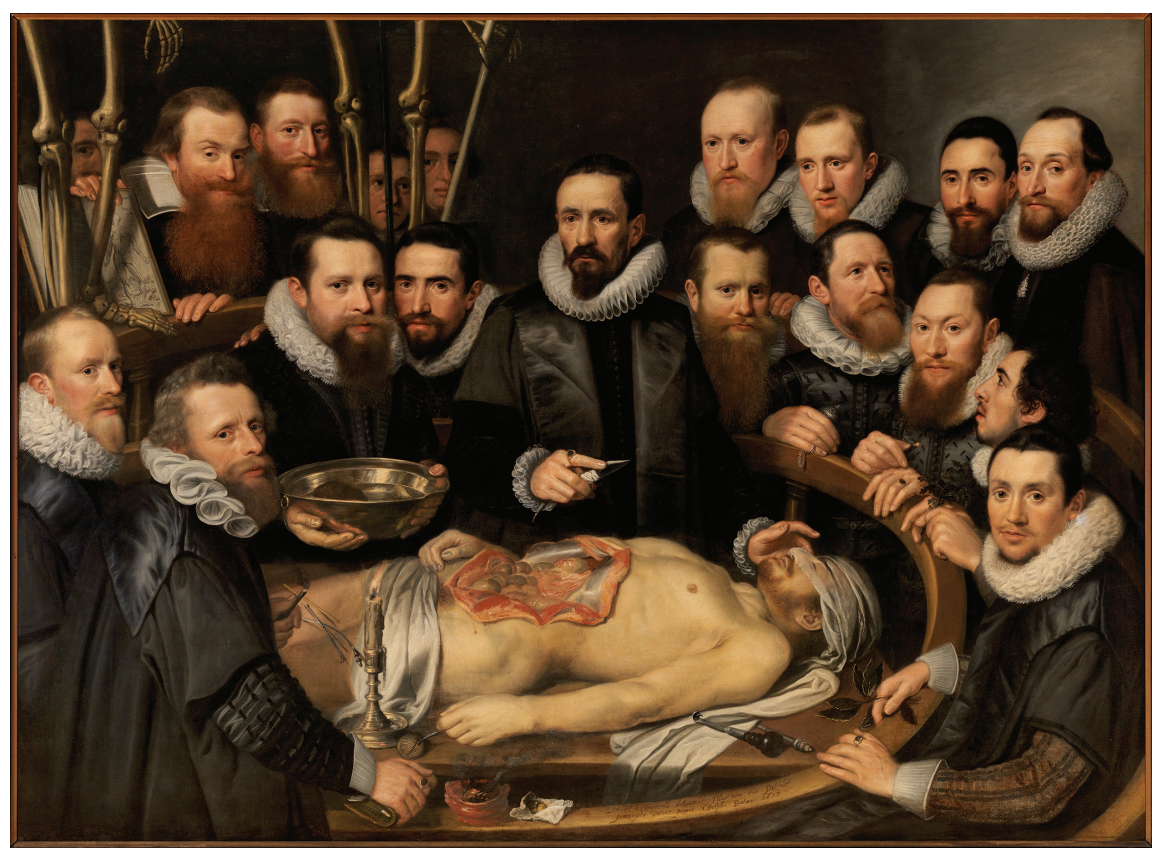

Fig. 3: Michiel Jansz van Mierevelt, Anatomy lesson of Dr Willem van der Meer, 1617, Museum Prinsenhof, Delft.

\section{Anatomy}

As we have seen, one reason why students from all over Europe were drawn to the universities in Padua, Bologna, and Montpellier was the excellent practical training offered there. This was coupled with a major second factor: the quality of the anatomical teaching at these universities. We might be tempted to ask to what extent a detailed anatomical knowledge was of use to a physician at a time when the vast majority of illnesses were not traced to pathological changes in organs or anatomical structures. Learned physicians - those practicing north of the Alps in any case - hardly concerned themselves with surgery, for which

286 Welsch, Consiliorum (1676), pp. 391-2: “Helidaeus tactu aquositatem subesse deprehendit”. 
good anatomical knowledge was of obvious significance. Nevertheless, the anatomical Renaissance not merely reflected a natural-philosophical interest in the human body. From a contemporary medical perspective, it was very much connected to the tangible hope that diseases could be better understood, identified, and treated with the help of precise anatomical knowledge, all the more so since the anatomical teaching of the day also dealt in a wider sense with the physiological functions of the organs and body parts. ${ }^{287}$

Anatomical knowledge was imparted on the one hand in lectures based on authoritative texts, such as Galen's anatomical writings, the parts of Avicenna's Canon medicinae that were devoted to anatomy and Anathomia by Mondino de Luzzi (c. 1270-1326). Only scattered sixteenth-century student notes on anatomy lectures have been identified so far, however. In 1551, Handsch took extensive notes on Falloppia's lecture about Galen's work about skeletal anatomy (De ossibus). Falloppia went through the numerous bones systematically, from the skull including the teeth - to the feet. He explained the various terms, described the structure and position, and sometimes the function of the bones. ${ }^{288}$ Handsch also took some notes on a general introductory lecture by Antonio Fracanzano about the different parts of the body. ${ }^{289}$ As those of other students, however, Handsch's notebooks give prominence to what the anatomists explained on the occasion of an anatomical demonstrations.

Historical research has so far shed little light on the details of anatomical teaching demonstrations and the specifics of what students learned there. Until very recently, the most important source for Padua was the Acta of the Natio germanica, which recorded in short minutes the events of the academic year including the anatomies that were performed. ${ }^{290}$ As I have shown at length elsewhere, ${ }^{291} \mathrm{stu}$ dent notes provide a much richer and more nuanced view of anatomical teaching. Georg Handsch took in-depth notes on anatomies, and we can also look at the extensive anatomical notes from two further medical students in Padua around the same time, Johannes Brünsterer (or Prünsterer) from Nuremberg and another who cannot be identified with certainty but may have come from Helmstedt. ${ }^{292}$ Further

287 Stolberg, Post-mortems (2017); as Handsch noted, some of the functions of the body and its part were ideally studied on the living, as Vesal had [allegedly] done on a Jew (Cod. 11210, fol. 191). 288 Cod. 11210, foll. 34v-40v; Franciscus Michinus later published his notes on Falloppia's lecture on De ossibus (Falloppia, Expositio (1570)).

289 Cod. 11210, foll. 187r-191r.

290 Favaro, Atti (1911); the Acta are the principal source also for the latest comprehensive overview of anatomical teaching in Padua by Cynthia Klestinec (Klestinec, Theaters (2011)).

291 Stolberg, Teaching anatomy (2018).

292 Universitätsbibliothek Erlangen, Ms 909; Staats- und Universitätsbibliothek Göttingen, Ms Meibom 20; Helmstedt University was only established in 1576, however. 
student notes are extant on the anatomical demonstrations of Fabrizi d'Acquapendente and Giulio Casseri in late sixteenth-century Padua. ${ }^{293}$

While studying in Padua, Handsch witnessed the complete, systematic dissection of a cadaver for educational purposes multiple times. Soon after he had arrived in December 1550, he included a description in his notebook of how Alessandro Sarego from Verona, who had recently taken over the surgical and anatomical instruction, dissected the body of a very corpulent woman while in keeping with the traditional division of labor - another professor, presumably Antonio Fracanzano, expounded on what was being shown. ${ }^{294}$ The cadaver had an unusual history. As Handsch noted in the margin, the woman was not a criminal but was herself the victim of a crime. Her husband had strangled her and thrown her into the water because she refused to earn money as a prostitute. The man was decapitated and likewise dissected. ${ }^{295}$ In the winter of 1551-52, Gabrielle Falloppia took over the chair of anatomy and surgery. Handsch documented two anatomical demonstrations that took place that same winter. ${ }^{296}$ As Andreas Vesal had done some years before, Falloppia combined the tasks of the lecturer, who explained and expounded upon what was being shown, with those of the sector who dissected and prepared the cadaver with his own hands. Handsch was also still in Padua when Falloppia, according to his own account, performed a further public demonstration on a cadaver in the winter of $1552-53 .{ }^{297}$ In the following years, Falloppia developed a very active practice of dissection. Just in the winter of 1557-58 he dissected seven cadavers, according to Joachim Curaeus. ${ }^{298}$

Historical research about the anatomical practice at universities in the sixteenth century has concentrated for the most part on the public anatomical

293 Cf. Stolberg, Learning anatomy (2018).

294 Cf. the edition and translation of Handsch's notes on this anatomical demonstration in Mache, Anatomischer Unterricht (2019). Sarego was appointed in December 1550 and taught until Falloppia took over a year later (Facciolati, Fasti, p. 387). Handsch's notes on the other participants are contradictory. First he wrote of "D. Antonio Frankenzano legente et demonstrante" (Cod. 11210, fol. 187r), but later of "D. Appellato legente" (ibid., 191v, marginal note). Provided Handsch did not simply make a mistake here, it is most likely that Apellatus only read out an anatomical text, while Fracananzo commented on what he saw as well as on the text that had been read out and thus directed the event.

295 Cod. 11210, 191v.

296 In ibid., fol. 187r, Handsch listed the dissections he saw. He inserted his notes on subsequent dissections under Falloppia in his notes in the margins, between the lines and sometimes also on additional slips of paper.

297 Falloppia, Observationes (1561), fol. 65r. Handsch's notes do no not explicitly document this dissection.

298 Adam, Vitae (1620), p. 205. 
demonstrations, which were great events in the life of the university, attracting prominent figures from inside and outside the university. Some places even had their own anatomical theaters built. Handsch's notes as well as those of other contemporary students show, however, that these public events were by no means the only opportunity students had to see the anatomical structures of the human body with their own eyes and to commit them to memory. There were also various "private" dissections ("anatomiae privatae") for a small number of - presumably paying - students. Handsch mentioned a number of such anatomiae privatae. ${ }^{299}$ They often covered particular areas of the body or body parts, like the head. Unlike with the large public demonstrations, students here could observe the structures up close, rather than from up in the stands of a large anatomical theater.

Practical anatomical teaching was not limited to the dissection of human cadavers. The dissection of animals proved to be a welcome addition. Dogs and other animals, as Handsch learned, had the same physiological functions ("operationes") as human beings. It was thus thoroughly instructive to practice anatomy on a dog ("in eo exercere anatomia"), which Falloppia did with his students. ${ }^{300}$ Observed by his students, Falloppia also dissected simian and bovine eyes and demonstrated the external eye muscles. Other students, too, documented such animal dissections, describing for example Falloppia's dissection of a dog and an ape in an anatomia privata. ${ }^{301}$ Animal dissections were particularly useful in understanding fetal development and the changes of the womb during pregnancy. Pregnant women on the dissecting table were a rare occurrence. In Handsch's Padua years, Falloppia dissected at least two pregnant ewes. Students at this opportunity could see the fetus, which Falloppia likewise opened up to show the students the pulmonary vessels. ${ }^{302}$

As a supplement to the demonstrations with cadavers, anatomists took recourse to prepared specimens and visual media. Prepared skeletons were useful for learning the numerous bones in the human body and their spatial relation to one another. Handsch described in his Padua notes, apparently taken during a lecture on Galen's De ossibus, what he saw on such a skeleton ("Quae in skeleto vidi”), which was held upright by an iron rod. ${ }^{303}$ Shortly thereafter, he worked with a real skull, taking extensive notes on the cranial bones and sutures and

299 Cod. 11210, fol. 21v, fol. 23v, fol. 28r and foll. 144v-145v.

300 Ibid., 191v; see also ibid., fol. 194r.

301 Staats- und Universitätsbibliothek Göttingen, Ms Meibom 20, foll. 127r-143v.

302 Ibid., fol. 11r.

303 Ibid., fol. 30v; probably on the same occasion, he made further notes on the anatomy of the spine (ibid., foll. 38v-40v). 
illustrating them with a small drawing. ${ }^{304}$ In his teaching, Falloppia also used anatomical illustrations or sketches to elucidate the complex anatomical structures such as the various layers of the eyeball and the "humors" inside it. ${ }^{305}$

Padua was therefore a place where prospective physicians could gain extensive, detailed anatomical knowledge with their own eyes and aided by the explanations of an experienced anatomist and surgeon. Over many pages, Handsch noted down what he was learning about the structures within the three body cavities - the cranial, thoracic, and abdominal cavities - and named the numerous bones, muscles, and tendons of which the human body is made. The anatomical demonstrations were generally connected with physiological explanations. Students not only saw the heart valves but also learned their function. According to contemporary teachings, they prevented the blood from flowing backwards, which, upon the expansion of the ventricle (diastole), was pulled from the large vena cava into the heart and pushed during systole into the lung and into the aorta, here together with the vital spirit, the spiritus vitalis, that was generated in the heart. ${ }^{306}$

Handsch's notes on the anatomy of the female genitalia are especially detailed. The "secrets of the female body" had long attracted heightened medical interest. As we will be seeing, sixteenth-century physicians also increasingly concerned themselves with diseases of women that had their sit or origin in the genitalia and above all the uterus, which marked the fundamental anatomical and physiological difference between man and woman. ${ }^{307}$ Through his own research in the field, Falloppia distinguished himself in this regard. He was the first to provide a precise description of the parts still known today as "Falloppian tubes", which unlike the seminal vessels in man, he found, were not connected to the testes but ended in the space below them, widening like the opening of a trumpet or tuba - hence the name. ${ }^{308}$ As Handsch learned, the passageways below the female "testiculi" opened, especially with the movement and warmth of coitus, allowing the female seed to enter the womb. This corresponded with the Galenic doctrine, according to which not only a male seed contributed to conception but also a female seed, ${ }^{309}$ which served "as it

304 Ibid., fol. 38r-v.

305 Ibid., fol. $27 \mathrm{r}$.

306 Ibid., foll. 17v-18r.

307 Cf. Stolberg, Woman (2003).

308 Falloppia, Observationes (1561), foll. 195v-196v.

309 E.g. Neefe, De missione (1548), conclusio I.1: “Corpora nostra ex sanguine, et maris foeminaeque semine conflata esse constat." 
were as nutrition for the male [seed]". ${ }^{310}$ Falloppia also explained to Handsch and to his fellow students that accounts of a "virgin's membrane" ("hymen") belonged to the realms of fantasy. He had, he said, dissected three virgins and found no hymen. Bleeding during the first act of intercourse was due to the narrowness of the vagina and was from burst veins. ${ }^{311}$ He would later correct himself, however: with certain virgins one could find a "membrana nervosa", with a hole in the middle large enough to allow menstrual blood to pass. ${ }^{312}$

The principal purpose of anatomical teaching was to convey anatomical knowledge that was, where appropriate, supplemented by references to physiological and pathological contexts and their diagnostic and therapeutic significance. Beyond this, students had the opportunity to gain the manual skills, the craftsmanship that they would require later when they wanted or had to dissect a corpse themselves, possibly in front of colleagues or a larger audience. They knew only too well from the anatomical demonstrations of their experienced teachers how difficult it was to identify, separate and distinguish the various anatomical structures. For good reasons, Handsch added a reference from Galen to his anatomical notes who had admonished physicians to practice anatomy on animals first to develop the necessary skills. ${ }^{313}$ Vesal, on his part, had emphasized how valuable it was for students to try their hand at the task. ${ }^{314}$

Handsch made note of a few well-known basic rules, for example that the dissection of a cadaver was best begun with the abdominal organs because the entrails began to rot particularly quickly. ${ }^{315}$ But not only this; he also noted down the various instruments needed: from the different scalpels to the small knife Falloppia preferred, the probe used to explore vessel openings, the sponges to absorb fluids, the oil that made it easier to separate the muscles from one another, and even the burning candles which generally served as a light source at the time (cf. Fig. 3). ${ }^{316}$ Handsch also wrote down the practical procedure: removing the hair (or fur in the case of animals), the two long, cross-shaped cuts used to open the abdomen, longitudinally from the sternum over the navel to the pubic bone and then across the navel on both sides, followed by folding back of the abdominal wall, initially only

310 Cod. 11210, fol. 9v.

311 Ibid., fol. 10r.

312 Falloppia, Observationes (1561), fol. 194r-v.

313 Ibid., fol. 193r.

314 Vesal, De humani corporis (1543), p. 547; cf. Carlino, Books (1999), pp. $188 \mathrm{f}$.

315 Cod. 11210, $192 \mathrm{v}$.

316 Ibid. 
on one side. ${ }^{317}$ And he learned little practical tricks, for example that when dissecting the liver, one could first tie up the veins with thread to prevent bleeding. ${ }^{318}$

The anatomical instruction in Padua and other Northern Italian universities such as Bologna and Ferrara ${ }^{319}$ was of such a quality that abroad only the universities in Paris and Montpellier - at best - could keep pace. The one in Montpellier regularly practiced educational anatomies already in the early sixteenth century. For just the time between 1526 and 1535, records of twenty-nine dissections are extant. $^{320}$ The university even had its own anatomical theater. ${ }^{321}$ As in Padua, not only the corpses of executed criminals were dissected ${ }^{322}$ but also those of people who died in accidents ${ }^{323}$ and of deceased hospital occupants. ${ }^{324}$ Dissections continued to be actively practiced later on as well. In his memoir, Felix Platter, who studied in Montpellier in the 1550s, told of several human dissections, but also of one ape dissection. ${ }^{325}$

At German universities, the practice of anatomical teaching was by far less intensive. Anatomical demonstrations only took place every few years, if at all. ${ }^{326}$ As late as 1572, Johann Schwartz explained that in "Germany” it was only possible to learn anatomy on cadavers in Basel, under Felix Platter. ${ }^{327}$ There are extant reports of earlier anatomical demonstrations at German universities. At the university in Wittenberg, for example, the first public anatomy took place in

317 Ibid., 194r.

318 Ibid., 192v. In her detailed analysis of anatomical education in Padua in the sixteenth century, Cynthia Klestinec described the teaching of concrete practical anatomical skills, especially in the context of private anatomies, and the students' interest in them as a new phenomenon, which she attributed to institutional and professional changes in the last two decades of the sixteenth century (Klestinec, Theaters (2011), pp. 153-155 and p. 225, note). Handsch's notes make it clear, however, that this development began much earlier. It is just not well documented in Klestinec's principal source, the Acta of the German Nation (Favaro, Atti (1911)).

319 Cf. Lind, Pre-Vesalian anatomy (1975), pp. 307-316.

320 Germain, Les étudiants (1876), p. 33.

321 Bibliothèque de la Ville de Montpellier, Manuscrits Germain, Ms. 111, Liber procuratoris (copy), fol. 214r, fol. 232r, fol. 233r and fol. 234r); Dulieu, La médecine (1979), p. 180.

322 E.g. Bibliothèque de la Ville de Montpellier, Manuscrits Germain, Ms. 111, fol. 213r and fol. 229r.

323 Thus, in 1532, a woman who had drowned in a watermill outside the town (ibid., fol. 214r). 324 Ibid., fol. 220r and fol. 243r.

325 Cf. Platter, Tagebuch (1976), p. 151, p. 187, p. 193, pp. 207-8 (on the dissection of a monkey under Guillaume Rondelet), p. 235, p. 238, p. 241 (on the dissection of a woman and of a girl), p. 259 and p. 261; see also Dulieu, Félix Platter (1991), pp. 17-20.

326 Kuhn, Studenten (1971), p. 36.

327 HStA Stuttgart, A 282, Bü. 1301, letter from Johann Schwartz to Duke Ludwig of Württemberg, October 1572. 
1526, with Augustin Schurff showing the anatomy of the head to an audience. ${ }^{328}$ But as far as we can tell today, there was no regular and reliable anatomical teaching at German universities and that situation was not to change soon.

\section{Pharmacy and Botany}

Along with anatomy, the teaching of medical botany - of the numerous medicinal plants or simplicia - took on increasing importance in university teaching in the sixteenth century. Medicinal botany established itself as an independent subject of instruction taught by specially appointed professors. ${ }^{329}$ A key factor in this pronounced rise in significance was once again the increased orientation in medical teaching towards the needs of medical practice. Thorough botanical and pharmaceutical knowledge was considered absolutely essential for a successful medical practice. And there were other developments that supported and encouraged this renewed appreciation of medical botany. The humanists rediscovered Galen's work on medicinal plants (De simplicibus) and the great pharmacological treatise by Dioscorides (Res medica). The commentary on Dioscorides by Handsch's later mentor Mattioli became the central pharmacological reference work in the second half of the sixteenth century. ${ }^{330}$ Since the Middle Ages, trade had also been bringing with it increasing numbers of exotic plants, and north of the Alps, physicians and apothecaries were discovering a native flora that found no mention in the works of Galen, Pliny, and other authorities who had practiced in more southern climes. With the traditional classification of healing plants according to qualities (cold, hot, dry, and moist) as a starting point, there also developed an awareness and an appreciation of the empirically observable "specific" effects of medicinal plants on particular organs or humors and against specific illnesses or complaints. ${ }^{331}$ Handsch reported that, in one instance, his professor Fracanzano even prescribed a sick patient black hellebore specifically "so that we would see its effects". 332

328 Koch, Anatomie (2003), p. 169.

329 Overview in Reeds, Botany (1991).

330 Mattioli, Commentarii (1554; 1565; 1570); Ferri, Dioscoride (1997); Fausti, Complessa scienza (2001); Ciancio, Many gardens (2015); cf. Reeds, Botany (1991), pp. 21f.; biographical surveys in Fabiani, Mattioli (1872), with an edition of relevant sources; Ferri, Mattioli (1997); Hejnová, Mattioli (2001).

331 See my discussion of drug effects in the chapter on empirical knowledge.

332 Cod. 11238, fol. 121r, "ut nos videremus eius operationem". 
A physician was expected to know what the plants he was prescribing looked like. Insufficient experience in this respect could quickly lead to disgrace, a humiliating experience that Handsch was not spared. He repeatedly made note of errors he made in the identification of plants, for example when he mistook storksbill (erodium) for Venus' comb (pecten veneris) and had to endure the lecture of someone who knew better. ${ }^{333}$ He noted elsewhere that he wanted to protect himself in the future from a similar "disgraceful error" ("turpis error"), after having falsely declared a common field plant to be Alexanders (smyrnium) in front of a Wittenberg student. ${ }^{334} \mathrm{He}$ also failed to impress Collinus on numerous occasions when he misidentified plants. ${ }^{335}$ But even the famous Mattioli - and this Handsch seems to have noted with a certain sense of satisfaction - was sometimes unable to identify plants correctly. ${ }^{336}$

If future physicians wanted to appear capable in the eyes of their patients, they had to acquire a broad and practice-oriented knowledge of the numerous known medicinal plants and the various ways they were to be administered. Some of this could be gained from lectures and books. In one of his Padua notebooks, Handsch took extensive notes based on Matteo Cortis's explanations of pharmacological indications, dosage forms, and dosages. His notes include references to syrups that were used for a hot, cold, dry, or moist intemperies, followed by syrups, waters, and numerous healing plants (simplicia) as well as mixtures of herbs (composita) that served the intended digestion, dissolution, mobilization and evacuation of bilious, black-bilious, and phlegmatic matter. After this, he listed remedies that were said to strengthen, warm, or cool specific organs or body parts like the head, as well as instructions on how to apply enemas and ablutions and use poultices and plasters. These explanations were accompanied by numerous formulas for prescriptions and dosage information. ${ }^{337}$

Herbal books furthermore provided prospective physicians with entries about a host of medicinal plants introduced one after the other, with their characteristics and effects. ${ }^{338}$ Handsch made notes of such works as Leonhard Fuchs's De historia stirpium, which, already in its early editions, covered well over 300 plants, listing them in order with their Greek, Latin, and German names. It further included their

333 Cod. 11210, fol. 121v; similarly Cod. 11183, fol. 40v: "Turpe me dedi."

334 Cod. 11210, fol. 125v.

335 Ibid., fol. 120v: "Turpiter me dedi coram Collino".

336 Ibid., fol. $124 \mathrm{v}$.

337 Cod. 11210, foll. 94r-114r. Corti (or Curzio) was the author of a treatise De dosibus, of which only an edition of 1561 is known (Brambilla, Scuola Longobarda (1781), pp. 1-4). Perhaps Handsch had access to lecture notes.

338 Overview in Arber, Herbals (1986). 
external appearance, the preferred habitat, the blooming period, the individual mixture of the four basic qualities (temperies), and the medicinal properties ascribed to them by Dioscorides, Galen, Pliny, Theophrastus, and other ancient authors. $^{339}$

Herbal books were valuable as the source of theoretical knowledge and they could be useful for reference. But even when they featured - as did Fuchs's work - illustrations of the healing plants that were more or less true to nature, they only gave the physician a limited ability to recognize and name the plants in question. The illustrations were black and white woodcuts that at best were colored, on occasion, by the owner of the book or by somebody commissioned to do the coloring by hand (and by no means necessarily from nature). The student's own visual inspection and experience with real plants remained indispensable. The great significance that was attached at the time to a precise knowledge of the numerous medicinal plants for a successful medical practice was thus also decisive in the emergence of an important innovation, which still shapes the cityscape of some university cities today: the establishment of botanical gardens for educational purposes. This new development had its beginnings in Italy and soon spread to all of Europe. ${ }^{340}$

There was a large and famous botanical garden in Padua. The Orto dei semplici was founded in 1545, a few years before Handsch's arrival. ${ }^{341}$ Handsch's notes show just how much the medical students made use of the opportunity to familiarize themselves with the various medicinal plants. Under the heading "Plants I got to know in the garden in Padua", Handsch in one of his Padua notebooks presented dozens of plants that he had seen in the botanical garden, and sometimes at other occasions. With varying degrees of detail, he described the appearance of many plants, their blossoms and leaves, and sometimes also mentioned the taste, as with bitter absinth. He even described many well-known native plants, like chamomile, borage, and common bugloss in this way. And he occasionally drew the outline of a leaf, to show, for example how it was elongated or heart-shaped or had a serrated edge. Only in rare instances, in the case of moneywort or houseleek, for example, did he find it enough to simply write "nota”, meaning "known". His notes were limited to botanical characteristics; he made no mention of the particular illnesses for which the plants were used nor did he even indicate their temperies. Evidently, his notes were primarily meant to help him memorize the appearance of the plants and plant parts that he had seen

339 Fuchs, Historia stirpium (1542).

340 Bedini, L'orto (2007).

341 Minelli, L'orto botanico (1995); Cappelletti, Le piante (1995). 
with his own eyes; he was training his ability to identify and distinguish plants and plant parts rather than addressing their therapeutic application. ${ }^{342}$

Establishing botanical gardens for the purpose of teaching students was a painstaking and costly task, and this impressively underscores just how much significance was now being attached to arriving at a medical knowledge of medicinal plants through personal observation. But the significance of these botanical gardens in teaching students must not be overstated either. Even in Padua, physicians in training found other ways of experiencing plants and thus acquiring botanical knowledge. By implication, this means that even when no botanical garden was available at a university, botanical knowledge could still be imparted in ways other than through books.

One obvious possibility here - one that has so far found little consideration in historical research - is that students visited private gardens. ${ }^{343}$ There are countless indications from Padua and Prague, but also from Augsburg, Nuremberg, and other cities, that the owners of private gardens - especially apothecaries and physicians - grew native and exotic plants and showed them to others. ${ }^{344}$ Handsch in his Padua notes repeatedly mentioned native and exotic plants that he had seen in the garden of his professor Antonio Fracanzano. ${ }^{345}$ In the garden of a certain Daniel or Daniele - possibly an apothecary - he found gladiolas and lemon balm. ${ }^{346}$ In the same entry - though he might have added this later - he referred to clematis flammula Jovis shown to him by a certain Thaddeus "in his garden" ("in suo horto"). ${ }^{347}$ One of the plants he saw when visiting a certain Cetterius was Spanish chamomile root (piretrum). ${ }^{348}$

Students furthermore sought to deepen their knowledge of botany in the wild. With acquaintances, Felix Platter went on botanical excursions near Montpellier. ${ }^{349}$ Strobelberger later praised the wealth of plants in the fields, olive groves, vineyards, woods, mountains, hills, rivers, lagoons, and the sea there. ${ }^{350}$

342 Cod. 11210, foll. 115r-120v: "Herbae quas didici in horto Paduano".

343 See, however, Ciancio, Many gardens (2016), p. 37, on Pietro Andrea Mattioli, who praised the garden of Maffeo de Maffei in Venice in this respect.

344 Lorenz Scholz even devoted a separate publication to a simple list of all the plants in his garden in Breslau (Scholz, Catalogus (1594)), which he had established seven year before; see also Rindfleisch et alii, Epigrammata (1594).

345 Cod. 11210, fol. 117r: "Vidi in horto Frankenzanii".

346 Ibid. The entry is followed by: "Item in apotheca monstravit lapatum, item hyacinthum." One of Handsch's fellow students was called Daniel Cellarius.

347 Cod. 11210, fol. 120v.

348 Cod. 11183, fol. 40v.

349 Platter, Tagebuch (1976), p. 219 and p. 222.

350 Strobelberger, Laureationem (1628). 
Handsch, too, reported how went to the country ("in agro") with some people and documented the herbs that he saw on this occasion, ${ }^{351}$ along with the plants that Fracanzano had pointed out to them at the riverside. ${ }^{352}$ The repeated mention of Fracanzano in this context also shows that students by no means only learned about the various healing plants from the professor who was responsible for teaching about the simplicia; in Handsch's time this was Falloppia.

In his early years in Padua, Handsch also learned how to press and dry plants and then collect them in a book. He saw this when visiting a certain Ladislaus, who was presumably a fellow student who showed him various plants in the botanical garden. Thus he knew that one could not simply put fresh plants in such a book but had to press and dry them first; otherwise they would rot. ${ }^{353}$ The production of such "herbaria viva" was a relatively new technique. Their invention is generally attributed to Luca Ghini (1490-1556), who taught medical botany in Bologna and Pisa and founded the botanical gardens in Pisa and Florence. ${ }^{354}$ The herbaria soon spread beyond the Alps. In the late sixteenth century, Caspar Ratzenberger compiled two magnificent, multi-volume herbaria within just a few years. ${ }^{355}$

Aspiring physicians in Padua and other places did not only have to familiarize themselves with a multitude of medicinal plants and more generally with all sorts of plant-, animal- and mineral-derived medicinal substances; they also had to be able to recognize them in a processed form and learn how medications were produced. As a rule, medications were manufactured or at least blended at the physician's behest by apothecaries and their assistants. Basic pharmaceutical knowledge was, however, essential for physicians. In the case of herbal infusions or decoctions, brewing the plant in hot water might be enough. But even here, and most definitely when prescribing syrups and electuaries, pills or tablets (we may imagine them like small cookies), the physician had to bear in mind the taste and possibly consistency. Otherwise, as we will see, physicians could expect to meet with considerable resistance from the patient. It was also important for the physician to know how the different ingredients interacted with one another, and which ingredients he had to add to achieve the desired consistency and taste. Not least of all, he had to ensure that the prescribed medicinal mixture would not quickly decompose or spoil.

351 Cod. 11210, fol. 119v.

352 Ibid., fol. 117v.

353 Ibid., fol. 115r.

354 Arber, Herbals (1986), pp. 138-143; Findlen, Death (2017).

355 Forschungsbibliothek Gotha, Chart. A 152-155; Stolberg, Konservierte Pflanzen (2019); on the second herbarium vivum, which today is in Kassel, see Schaffrath, Läuse (2012). 
The apothecary were artisans, they learned a trade. As a rule, they did not go to university. Many of them were educated, however, ${ }^{356}$ and, most crucially, they could draw on a wealth of experience in dealing with medicinal substances. They knew how to judge the qualities of ingredients, and they had the necessary practical skills in producing medicines in their various forms. Physicians increasingly demanded and were granted the power to supervise apothecaries. But in practical matters, physicians stood to learn a great deal from them. In his later years, Handsch still often took note of what he had learned from apothecaries about certain medicinal plants and about the production of medications, and he even occasionally took guidance from them. ${ }^{357}$

For medical students, apothecaries played an even greater role. In some university towns, apothecaries were even involved in university teaching to a certain extent. During Handsch's Padua days, Antonio Fracanzano took his students not only to the botanical gardens to look at living plants, but also to apothecaries, where they could learn to identify and evaluate the blossoms, leaves and roots of medicinal plants in a dried and processed state, for example grated guaiacum wood. ${ }^{358}$ In his Padua notes, Handsch repeatedly named the plants and plant parts he had seen at the apothecary's, such as the leaf of a mandragora, shown to him by an apothecarius. ${ }^{359}$ In Montpellier, Strobelberger praised the local apothecaries, chief among them Laurentius Catellanus, who were very learned ("doctissimos"). They presented the entire materia medica privately and publicly, showed native and exotic plants, and demonstrated the production of complex medicinal products such as theriac, mithridate, and alkermes. ${ }^{360}$ Felix Platter during his time in Montpellier made a point of lodging with Catellanus and would profit very much from this. He was learning a lot, he wrote to his father in 1553, and that he would "lodge in the pharmacy, in which my master has much to do, so much that he needs four or five servants," and would "learn about everything there daily."361

Prospective physicians were also well-advised to continue cultivating their botanical knowledge after they had completed their studies. Handsch as a young physician compiled further lists of "simplicia" that he had seen himself, beginning with a list of "simples I learned about in Prague in 1554". ${ }^{362}$ There were no

356 Hoppe, Bildungshungrige Apotheker (1992).

357 Cod. 11183, foll. 147r-152v; Handsch used the word "docuit”, "he taught”.

358 Cod. 11210, fol. 140r.

359 Ibid., fol. 117r.

360 Strobelberger, Laureationem (1628), p. 18.

361 Platter, Tagebuch (1976), p. 157.

362 Cod. 11210, fol. 120v-125r: "Simplicia quae Pragae didici”. 
botanical gardens there, but private gardens offered ample material to be viewed. He repeatedly mentioned the garden of Collinus, for example, and noted that Collinus showed him aristolochia rotunda there. ${ }^{363}$ It is possible that he was referring to the Angel's Garden, where Collinus had established his school, but Handsch also hinted at the existence of a second, possibly private garden belonging to Collinus. His medical teachers too, Lehner and Gallo, had their own gardens in which Handsch saw noteworthy plants such as loosestrife (lysimachia) and savory (satureja). ${ }^{364}$ References to further private gardens may be surmised from entries such as "at old Wenzel's I saw florem Martii [hyacinth? common narcissus?]”, "I saw meadowsweet at Klaus's”, and "I saw lavender at Blasius's". 365

The young Handsch moreover went on botanical excursions in the company of Mattioli. In 1555, he listed a good dozen plants under the title "Cum Matthioli et aliis ivimus herbatum"366 and he explicitly mentioned M. Thadeus and M. Iacobus Camenicenus. ${ }^{367}$ As late as 1563, he went on a botanical excursion ("herbatio") with Mattioli and an apothecary. ${ }^{368}$ In his Innsbruck years as well, he continued his student notes about simplicia and described among other things several plants in the Archduke's garden in Ambras. ${ }^{369}$

\section{Surgery}

Another feature that distinguished the universities in Northern Italy and Montpellier from those north of the Alps was the importance they gave to the surgical training of prospective physicians. In Italy - and the same holds for Spain ${ }^{370}$ surgery had been firmly established at the universities since the Middle Ages. ${ }^{371}$

363 Cod. 11205, fol. 564v.

364 Cod. 11210, foll. 124r-125v.

365 Ibid., fol. 121r: "Paeoniam vix cognovi in horto D. Ulrici"; "vidi apud Adamum" (ibid. fol. 122v); "filipendulam vidi apud Claudium" (ibid., fol. 123r); "gariophyllam in horto Collini optime vidi” (ibid.); “apud presbyteram Venceslaum vidi florem Martii” (ibid., fol. 125r).

366 Ibid., foll. 123v-124r.

367 Probably Handsch was referring to the physician and clergyman Jacobus Camenicenus († 1565), whom he mentioned repeatedly.

368 Ibid., fol. 126r; according to Handsch, their destination was the "Devil's hole" ("foramen diaboli”); possibly this refers to the Průrva Ploučnice, an artificial, partly underground canal at the end of a reservoir in the area around the former Wartenberg (Stráž pod Ralskem) on Rollberg, not far from Handsch's home town Leipa.

369 Ibid., fol. $127 \mathrm{r}$.

370 López Pinero, Ciencia (1979), pp. 360-368.

371 Siraisi, Faculty of Medicine (1992), pp. 381f.; Fischer, Hartmann Schedel (1996), p. 54. 
In Bologna, for example, set texts for surgery, which the professors had to read from and comment on, were listed in the statutes as early as 1405, and leading medical authors like the Florentine Dino del Garbo (1280-1327) concerned themselves with surgical topics. ${ }^{372}$ In sixteenth-century Italy, there were already quite a number of professorships for surgery, usually connected with anatomy and botany. Leading professors practiced surgery in all its aspects. Himself the son of a surgeon, Berengario da Carpi in Bologna, for example, was not only a famous anatomist but for twenty-five years occupied the chair of surgery there and was known as much as a surgeon as for treating internal diseases. ${ }^{373}$ Some graduates of Italian universities - including those from north of the Alps - later proudly carried the title of a doctor in medicine and surgery. Hartmann Schedel, for instance, who earned his doctoral degree in Padua in 1466, already practiced medicine under the title "Doctor utriusque medicinae". ${ }^{374}$ Paracelsus, too, called himself a "doctor of both medicines". Allegedly he studied in Italy for some time ${ }^{375}$ but the doctorate he is said to have earned in Ferrara cannot be verified. ${ }^{376}$ Some Italian universities, including Bologna and Padua, even offered a shorter course of studies that enabled students to earn only the title of doctor chirurgiae. ${ }^{377}$

In academic medicine north of the Alps, by contrast, surgery continued to live in the shadows. ${ }^{378}$ Some physicians bemoaned this state of affairs. "Contrary to the doctrine of the old physicians", the Chemnitz doctor Caspar Neefe (1514-1579) lamented in 1548, surgery had been separated from "physica medicina". ${ }^{379}$ At the University of Leipzig, Duke Moritz established a surgical lectureship in 1542. At first, the university used the money for other purposes but in 1554 Moritz' successor August insisted and Gregor Schett, doctor "in both medicines” was

372 Later published as Chirurgia cum tractatu eiusdem de ponderibus et mensuris nec non de emplastris et unguentis (Ferrara 1485; Venice 1536).

373 Bylebyl, Cardiovascular physiology (1969), p. 111.

374 Fischer, Hartmann Schedel (1996), p. 54.

375 Paracelsus, Grosse Wundartzney (1536), preface to the reader.

376 Ibid., dedicatory epistle to Emperor Ferdinand, 7 May 1536.

377 Nutton, Humanist surgery (1985), p. 80. Thus we find in Padua and Venice in the 1540s the "doctor chirurgiae" Franciscus Litigotus, and in April 1549 a doctorate in surgery is documented for a certain Paolo Casiccio, who had his fees waived because of his poverty (Bernardi, Prospetto (1797), p. 39 and p. 22).

378 Schlegelmilch, Surgical disputations (2021), esp. pp. 255-260; see also Schütte, Medizin (2017), pp. 272-276.

379 Neefe, De missione (1548), problema I. 
appointed. It is worth pointing out, in our context, that the professor was not only to teach medical students but also, in German, non-academic barber-surgeons. ${ }^{380}$

Two main causes of this marginal role of surgery in the learned medicine north of the Alps may be identified. For one thing, academically trained physicians were concerned that the manual aspects of surgery might be damaging to their scholarly dignity. The word "Chirurgie" in German and French or "chirurgia" in Italian - as with "surgery" in English - derives from the Greek terms for "hand" and "work", and the surgeon necessarily had to dirty his hands. In Italy, such reservations were apparently less widespread, perhaps because academic physicians had occupied an uncontested place there in the healthcare of even smaller towns since the late Middle Ages and did not feel the same need to set themselves apart from the manual aspects of medicine. In many Italian towns, they were even employed as medici condotti and paid a regular salary. ${ }^{381}$ The other reason was that, in German-speaking areas, barber-surgeons had been successful in broadening the scope of their activity to include not only hair and body care but minor surgery. They were organized in guilds and asserted their monopoly when it came to surgical cases, even against learned physicians. ${ }^{382}$

In Padua, Handsch met with conditions that favored the acquisition of surgical knowledge and skills. ${ }^{383}$ For good reason, Conrad Gessner recommended to the town of Zurich that the young Georg Keller be given a scholarship so he could study in Padua and gain surgical knowledge in particular. ${ }^{384}$ As in other Italian universities, the dual chair of anatomy and surgery in Padua, which linked the two fields, was advantageous to both. Presumably, Vesal was not particularly proficient at surgery considering his relatively young age and his limited bedside experience. However, Gabrielle Falloppia, Giulio Casseri, ${ }^{385}$ and Girolamo Fabrizi d'Acquapendente, who succeeded him in shaping the anatomical and surgical teaching in Padua, enjoyed excellent reputations as practicing surgeons and as anatomists.

380 Zaunick, Beiträge (1924/25).

381 Nutton, Continuity (1981).

382 Cf. Jütte, Ärzte (1991), pp. 20-22; Kinzelbach, Sozial- und Alltagsgeschichte (1994); see also below the chapter on bath-masters and barber-surgeons.

383 Nutton, Humanist surgery (1985).

384 Zentralbibliothek Zürich, Ms. S 85, N. 11, letter from Gessner to the town authorities in Zürich (I owe this information to Tilmann Walter).

385 On Casseri see Sterzi, Giulio Casseri (1909); Cunsolo, Giulio Casserio (2008); on Fabrizi see among others Favaro, Contributi (1922); Scipio, Girolamo Fabrizi (1978); Fossati, Girolamo Fabrizi (1988). 
Regardless of the paramount significance of manual work, of practical technical skills in surgery, university teaching in this field relied heavily on commenting on authoritative works. Professors were able to draw on a remarkable corpus of ancient, Arabic, and medieval works. Book Six of Paul of Aegina's compendium of medicine, which treated a broad range of surgical procedures in detail, ${ }^{386}$ served as an important foundation, along with Galen's Methodus medendi. The Hippocratic text on injuries of the head, the relevant passages of Aëtius of Amida and Oribasius, and the exhaustive treatment of Greek and Roman surgery in Celsus received less attention in the sixteenth century. ${ }^{387}$

No notes from surgery lectures in Handsch's hand have survived. On a few occasions, however, he wrote down what he learned about particular surgical procedures in the anatomy lessons taught by Gabrielle Falloppia, because Falloppia sometimes recounted his own experiences in surgery to his students.

Concerning the throat and esophagus, Falloppia discussed the removal of swallowed fish bones. Some, he explained, advised the use of a piece of dry sponge that was coated with sugar and lowered into the throat on a string. When, meeting with humidity, the sugar became liquid, the sponge expanded and could be pulled out, taking the fish bone with it. ${ }^{388}$

On the basis of anatomy, Falloppia gave his students an exact description of where to place the incision to drain the liquid accumulated in the abdomen in patients with massive abdominal dropsy (ascites). ${ }^{389}$ He explained that this procedure, called paracentesis was carried out by surgeons when drug therapy failed. He warned, however, that great caution was required as the procedure was dangerous. He himself had performed it on three patients and all three had died, one of them within a month. His listeners were therefore not to carry out a paracentesis of their own accord, but only if their patient explicitly demanded the procedure. The incision must not be made directly under the navel because this would damage the sinews of the straight abdominal muscles (musculi recti) which connected to the pubic bone. These were very sensitive to pain and would contract, which could result in fainting, and they also healed badly. It was better to place the incision in the fleshier parts to the left or right below the navel, keeping a distance of approximately three finger-widths from the pelvic bone. Here too, Handsch drew a small sketch. The procedure in this area was less painful

386 Paulos von Aegina, Sieben Bücher (1914), pp. 466-604.

387 On the following see also the excellent survey in Nutton, Humanist surgery (1985).

388 Cod. 11210, fol. 202r.

389 Ibid., fol. 144v-145v; Michinus, the editor of Falloppia's Observationes anathomicae, also described how Falloppia used the dissection of a dog to show him and other students how to proceed on humans (Falloppia, Expositio (1570), foll. 71r-76r). 
and the opening would heal better. The incision could be made lengthwise but Falloppia recommended doing a transverse cut. With dropsical patients, he said, the danger of damaging the intestines was not great. However, the incision should be made in such a way that the opening into the depth of the body would be covered again by superficial skin following the procedure. Furthermore, it was important to drain the liquid not in one sitting but in several steps. From a note in the margin we may surmise that Falloppia demonstrated the procedure for the students, using a dog ("in cane"): he first used a small knife to make a lateral incision in the skin before perforating the muscles below the incision and inserting a silver cannula ("cannula argentea"). ${ }^{390}$ Falloppia illustrated his explanations with cases from his own practice. He told of a dropsical peasant ("rusticus"), for example, in whose case simply scoring the abdominal skin was enough to produce two bowls full of liquid and to eliminate the pain in the tight, bulging belly. ${ }^{391}$

As part of his teaching on the anatomy of the abdomen, Falloppia also showed his students what the anatomical preconditions were for the development of an inguinal hernia. Hernias or intestinal hernias were common the time and feared, and they could become monstrous in size. ${ }^{392}$ Hernias were also considered a major cause of male infertility and could critically jeopardize a man's marriage prospects. Falloppia's students were allowed to feel for the hole in the groin of a corpse through which the spermatic cord went to the scrotum the most common opening for hernias in boys and men. They also learned about the different layers that had to be cut during such an operation. The anatomist gave his students a precise description of his procedure, which did not involve the commonly practiced removal of the testicle. The surgeon had to push the intestines back as far as possible, cut through the scrotum and its inner covering and then burn the region with a red-hot iron in such a way that the intestine could no longer move down. He warned against excessive optimism, however. He had healed some patients in this way, but with others the operation had not been beneficial. Similarly, he had successfully performed couching on one patient, but had destroyed the eye in the case of two others. ${ }^{393}$

Handsch even made notes on the technique of suturing. This is noteworthy because, given the circumstances at the time, Handsch could be quite sure he would never be assigned this task north of the Alps. He described at length how,

390 Cod. 11210, fol. 145v; a note above it, "D. Gallus Augustae”, probably refers to a case of dropsy that Andrea Gallo had treated in Augsburg, which is not further outlined here.

391 Cod. 11251, foll. 29v-30r.

392 See e.g. Baillou, Consiliorum medicinalium (1635), vol. 2, pp. 244-46, on the case of a man who carried large parts of his intestines in his scrotum.

393 Cod. 11210, fol. 195r-v, inserted leaf "De herniae curatione”. 
according to Falloppia, deep, penetrating abdominal wounds had to be sutured and illustrated the line of the suture with two small sketches. The common suture, he said, was the one which Albucasis called the furrier's suture ("pelliparorum"). Here, the muscles and the peritoneum were simply stitched back together as one. In Falloppia's eyes, however, this method was coarse and unsuitable. A far better suture was one that Galen had mentioned, albeit in obscure words, where muscle was sutured to muscle and peritoneum to peritoneum - in other words, working with the layers. ${ }^{394}$ At another occasion, responding to a student's request, Falloppia described the use of ants in the treatment of intestinal injuries. According to the old teachings, ants had to be set on the joined edges of the wound and their abdomens squeezed, causing them to bite. Then they were cut through in the middle and the process was repeated with more ants until the wound was closed up. He had never done this himself, however. Rather, he had sutured two patients with abdominal wounds using the (abovementioned) "furrier's suture", that is using one continuous thread. The thread could later be removed all at once in its entirety, though he did not think that leaving the thread behind would do great damage. Both patients had died, but there had reportedly been several men in the encampments who survived such intestinal wounds. ${ }^{395}$

Falloppia seems to have had quite an extensive surgical practice in Padua. Thus students who came with him on visits had the opportunity to familiarize themselves with surgical methods, to observe him doing the many small maneuvers that were decisive for the success of the treatment. From students' accounts we know that Falloppia not only treated a young man with a genital ulcer and "spermatic flux" and used a probe to find a bladder stone on another patient. ${ }^{396}$ According to Vettore Trincavella, Falloppia also used such a probe on a woman with a hard ulcer of the uterus ("scirrhus"). She subsequently died, reportedly because Falloppia accidentally punctured the uterus. ${ }^{397}$ Handsch further described in detail how Falloppia, in June of 1552, proceeded in the case of a grossly swollen lymph node in the groin of a twenty-year-old. The swelling, it was assumed, derived from a venereal disease ("ex coitu"). Here, Falloppia used a special double-layered dressing with four loose ends that made it possible to attach it to the thighs and belly. He applied an ointment that was supposed to bring the lymph node to "maturity". When the growth had softened

394 Ibid., fol. $144 \mathrm{r}$.

395 Ibid., fol. 198r, inserted leaf "De vulnere intestinorum”.

396 Padovani, Processus (1607), p. 166 and p. 165.

397 Ibid., p. 148; by all appearances, the notes were written by a German-speaking student who studied both in Bologna with Padovani and in Padua among others with Trincavella who told his students about Falloppia's misfortune. 
after a couple of days, Falloppia cut it open in the presence of Handsch, and blood and pus issued from it. Subsequently, Falloppia covered the wound with egg white and several layers of bandaging. ${ }^{398}$ Handsch furthermore observed how Falloppia cleaned a deep abdominal wound using a small cannula ("syphunculum") and then reapplied the dressing, ${ }^{399}$ and how, treating another young man, he lanced a phlegmon. ${ }^{400}$ He watched as the anatomist washed a head wound, closed it with two or three stitches, applied egg white against inflammation and then a very sticky, pitch-like substance made from barberry (berberis), which held the edges of the wound together. ${ }^{401}$

In Bologna and Ferrara as well, students were able to observe the treatment of surgical patients. One of Elideo Padovani's students in Bologna, for instance, learned about hemorrhoids that they would only heal when cut and cauterized, as he witnessed himself at the hospital ("ut in hospitali vidi"). ${ }^{402}$ Among the patients visited by prospective physicians and their teachers in Ferrara during the 1540s were also several who were treated surgically, some of them by both a physician and a surgeon at once. One approximately thirty-year-old man had injuries on his head and leg from the blows of a sword; the shin and muscle of the lower-leg were almost completely severed. He was visited first by a surgeon, who let his blood and treated the injuries with egg white and rose oil, and applied a hemostatic powder. Two days later, the professor - presumably Musa Brasavola - was called in to see the patient. The patient died several days later, however. With his praeceptor, the anonymous student note-taker also saw less serious surgical cases, for example that of a girl who had fallen and hit her head but was not even bleeding; another was a load carrier who had broken through an attic floor with a sack of flour on his shoulders and came to the praeceptor eight days later to seek advice about his painful ribcage. ${ }^{403}$

To date, there are no known sources for universities outside Italy that describe a surgical training program anywhere near as intensive as in Italy. Montpellier at least enjoyed a good reputation with respect to surgery, among other things. At the time when the Zurich city council opened the way for Georg Keller to go to

398 Cod. 11238, foll. 113v-114v; the treatment lasted for several weeks and initially the patient was visited twice a day. Handsch made detailed notes on seven such visits but was probably present at others as well.

399 Ibid., fol. 126v, “cum Falloppia”. The treatment lasted one month. Handsch's notes do not indicate how often he saw the patient himself.

400 Cod. 11205, fol. 570v.

401 Cod. 11238, fol. 131v.

402 Padovani, Processus (1607), p. 133.

403 Biblioteca Ariostea, Ferrara Ms Collezione Antonelli, Ms. 531, fol. 31r-v and fol. 47r-v. 
Padua, it gave the young Kaspar Wolff a scholarship to go to Montpellier. The instructions written for the two by Conrad Gessner say that both were to go to two lectures on internal medicine and one on surgery. They were to "accompany the physicians of internal medicine and surgery in their practice every day" and finally "become physicians of internal medicine and surgery." Gessner himself had studied in Montpellier and therefore was familiar with the local conditions. ${ }^{404}$

In German-speaking areas, surgery in the sixteenth and seventeenth centuries remained largely in the hands of barber-surgeons. Accordingly, the first comprehensive surgical textbooks in German-speaking areas - notably written in German, not in Latin, the language of scholars - were penned by surgeons like Hieronymus Brunschwig (c. 1450-1512) ${ }^{405}$ and Hans von Gersdorff (c. 1455-1529), ${ }^{406}$ who had been trained as craftsmen, not by academics. The most famous surgeons of Europe during the late sixteenth century, Wilhelm Fabry von Hilden ${ }^{407}$ and Ambroise Paré in France, ${ }^{408}$ did not carry the title of a medical doctor and did not teach at universities. As noted above, it is not certain either that Paracelsus, who published his Große Wundartzney (Great Book of Surgery) in $1536,{ }^{409}$ had an academic degree.

It was the physicians who had studied in Italy who, in the course of the sixteenth century, increasingly added surgery to academic medicine north of the Alps. Following a study visit in Bologna, Ferrara, and Padua, Johannes Lange, as early as 1550, advocated for a greater appreciation of surgery within learned, academic medicine in Germany. A number of his treatise-like Epistolae medicinales were dedicated to surgical subjects such as skull fractures, eye injuries, war wounds, and questions of bloodletting, and he also published a number of surgical case histories. ${ }^{410}$ In the late sixteenth century, the town physician of Alkmaar, Pieter van Foreest, who had also studied in Italy, even compiled a five-volume collection of surgical case histories from his own practice. ${ }^{411}$ However, a close reading reveals that both Lange and Foreest essentially only gave advice and perhaps applied ointments and dressings in these surgical cases. There is no conclusive evidence that they personally put their hand to the task.

404 “Ordnung” for Wolff and Keller, 22 May 1555, cit. in Schieß, Briefe (1906), pp. 16-18.

405 Brunschwig, Buch der Cirurgia (1497).

406 Gersdorff, Feldtbuch (1517).

407 Fabricius, Opera (1646).

408 Paré, Opera (1594); biographical sketch in Dumaître, Ambroise Paré (1986).

409 Paracelsus, Grosse Wundartzney (1536); cf. Vekerdy, Great Wound Surgery (2005), pp. 77-99. 410 Lange, Medicinalium epistolarum (1554), pp. 12-36, and idem, Secunda medicinalium epistolarum (1560), pp. 33-38.

411 Foreest, Observationum (1601). 
As late as 1600 , surgery continued to occupy no more than a marginal position in academic medicine north of the Alps. The fact that autopsy was practiced at universities to a much lesser degree there - autopsies required keen surgical skills - went hand in hand with physicians' greater reserve about any hands-on practice on the dead or the living body. As late as the middle of the seventeenth century, the surgeon Tobias Geiger - he was originally trained as a craftsman but later earned his doctorate - felt compelled to write a passionate call for surgery to be given a more prominent place in medical training. ${ }^{412}$ At this point, the interest in surgery among German-speaking physicians had already grown, however, likely not least of all thanks to the numerous students from north of the Alps who had gone to Italy and experienced the considerably higher status of surgery at the universities there. The example of Johann Konrad Zinn in Oettingen serves well to illustrate this point. Having studied in Padua, where he would have heard Fabrizi's lectures on surgery, he earned his doctoral degree in Basel defending a thesis on head wounds, clearly a surgical topic. He declared in a dedicatory letter that if you wanted to rightly call yourself a physician, you had to master all of medicine. Surgery was not only an essential part of medicine but it took precedence over the other parts because with internal diseases the physician had to serve nature, while in the case of surgical procedures he was her equal, and at times her superior. ${ }^{413}$

412 Bayerische Staatsbibliothek München, Cgm 3733, Tobias Geiger, Discursus medicus und politicus (1656); cf. Schlegelmilch, Selbstbewußtsein (2020); Meyer, Discursus (2021).

413 Zinn, Disputatio (1595), dedicatory epistle to Graf Wolfgang von Hohenlohe: "Chirurgia vero medicinae non modo pars essentialis est, sed prae caeteris insuper omnibus cum antiquitatis, tum artis (proprie quidem et seorsim absque naturae commercio consideratae) praerogativam obtinet." 